\title{
Technisch werkdocument HBO-Monitor 1995: De arbeidsmarktpositie van afgestudeerden van het hoger beroepsonderwijs uit het studiejaar 1993/1994
}

Citation for published version (APA):

van de Loo, P., \& Zuurbier, H. (1997). Technisch werkdocument HBO-Monitor 1995: De

arbeidsmarktpositie van afgestudeerden van het hoger beroepsonderwijs uit het studiejaar 1993/1994. Researchcentrum voor Onderwijs en Arbeidsmarkt, Faculteit der Economische Wetenschappen. ROA Working Papers No. 003 https://doi.org/10.26481/umarow.1997003

Document status and date:

Published: 01/01/1997

DOI:

10.26481/umarow.1997003

Document Version:

Publisher's PDF, also known as Version of record

Please check the document version of this publication:

- A submitted manuscript is the version of the article upon submission and before peer-review. There can be important differences between the submitted version and the official published version of record.

People interested in the research are advised to contact the author for the final version of the publication, or visit the DOI to the publisher's website.

- The final author version and the galley proof are versions of the publication after peer review.

- The final published version features the final layout of the paper including the volume, issue and page numbers.

Link to publication

\footnotetext{
General rights rights.

- You may freely distribute the URL identifying the publication in the public portal. please follow below link for the End User Agreement:

www.umlib.nl/taverne-license

Take down policy

If you believe that this document breaches copyright please contact us at:

repository@maastrichtuniversity.nl

providing details and we will investigate your claim.
}

Copyright and moral rights for the publications made accessible in the public portal are retained by the authors and/or other copyright owners and it is a condition of accessing publications that users recognise and abide by the legal requirements associated with these

- Users may download and print one copy of any publication from the public portal for the purpose of private study or research.

- You may not further distribute the material or use it for any profit-making activity or commercial gain

If the publication is distributed under the terms of Article $25 \mathrm{fa}$ of the Dutch Copyright Act, indicated by the "Taverne" license above, 
Technisch werkdocument HBO-Monitor 1995:

De arbeidsmarktpositie van afgestudeerden van het hoger beroepsonderwijs uit het studiejaar 1993/1994

Peet van de Loo en Hubert Zuurbier

ROA-W-1997/3

Researchcentrum voor Onderwijs en Arbeidsmarkt

Faculteit der Economische Wetenschappen en Bedrijfskunde

Universiteit Maastricht

Maastricht, april 1997 
ISBN 90-5321-206-X

\section{SEC97.053}

Inhoud 
Bladzijde

1 Inleiding 1

2 Dataverzameling en -verwerking 2

3 Herweging naar landelijke cijfers $\quad 6$

$\begin{array}{lr}\text { 4 Analyses } & 9 \\ 4.1 \text { Factoranalyse } & 9 \\ \text { 4.2 Typeringscriteria } & 10 \\ \text { 4.3 Opzet regressie-analyses } & 11 \\ \text { 4.4 De referentie-hbo'er } & 14 \\ \text { 4.5 Resultaten regressie-analyses } & 15\end{array}$

$\begin{array}{ll}\text { Bijlage } 1 \text { Overzicht gebruikte variabelen } & 25\end{array}$

Bijlage 2 Overzicht resultaten regressie-analyses 33 


\section{Inleiding}

Voor u ligt het technisch werkdocument behorend bij het onderzoek "HBO-Monitor 1995", waaronder ook de in 1995 specifiek voor de kunstensector ontwikkelde "Kunsten-Monitor" wordt gerekend. Dit jaarlijks terugkerende onderzoek had betrekking op de arbeidsmarktpositie van de afgestudeerden van het hoger beroepsonderwijs (hbo) uit het studiejaar 1993/1994. Het onderzoek bestaat uit een schriftelijke enquête onder (pas afgestudeerde) hbo'ers en wordt onder auspiciën van de HBO-Raad door het Researchcentrum voor Onderwijs en Arbeidsmarkt (ROA) te Maastricht uitgevoerd, in samenwerking met DESAN Marktonderzoek te Amsterdam. Het ROA voert hierbij de projectleiding en is daarnaast verantwoordelijk voor de instrumentontwikkeling, het databeheer, de weging, evenals de landelijke analyses en rapportages, terwijl DESAN de dataverzameling en -verwerking voor haar rekening neemt.

Dit technisch werkdocument bevat een technische toelichting op de uitvoering van het HBO-Monitor onderzoek voor zover deze informatie niet in de overige HBO-Monitor publicaties over het uitvoeringsjaar 1995 is opgenomen. Het werkdocument gaat in concreto in op de dataverzameling (hoofdstuk 2), het herwegen van de resultaten naar het landelijk totaal aan afgestudeerden uit het studiejaar 1993/1994 (hoofdstuk 3), en de uitkomsten van de gehanteerde analyse-technieken (hoofdstuk 4).

Voor de landelijke resultaten over HBO-Monitor 1995 wordt verwezen naar het landelijk rapport en statistisch supplement dat de HBO-Raad najaar 1996 heeft uitgebracht. ${ }^{1}$ Naast deze openbare rapporten zijn de resultaten over HBO-Monitor 1995 voor de deelnemende faculteiten van hogescholen in een vertrouwelijke instellingsrapportage opgenomen. De instellingsrapportage bevat niet alleen de gegevens over de arbeidsmarktpositie van de 'eigen' afgestudeerden van de hogeschool, maar ook van de daarmee vergelijkbare opleidingen van zusterinstellingen.

Daarnaast heeft het ROA de opzet en uitvoering van de data-entry, de codering van opleiding, beroep en branche evenals de data-cleaning in verband met het HBO-Monitoronderzoek op gedetailleerde wijze gedocumenteerd. Deze documentatie is in de eerste plaats voor intern gebruik opgesteld.

1. P.J.E. van de Loo, G.W.M. Ramaekers, R.K.W. van der Velden, H.M. Zuurbier (1996), De arbeidsmarktpositie van afgestudeerden van het hoger beroepsonderwijs, landelijk rapport HBOMonitor 1995, HBO-Raad, Den Haag.

P.J.E. van de Loo, K.J. Pagrach, (1996), De arbeidsmarktpositie van afgestudeerden van het hoger beroepsonderwijs, statistisch supplement, HBO-Monitor 1995, HBO-Raad, Den Haag. 


\section{Dataverzameling en -verwerking}

De onderzoekspopulatie in het uitvoeringsjaar 1995 bestaat uit afgestudeerden van het hoger beroepsonderwijs (hbo) die in Nederland in het studiejaar 1993/1994 het diploma van een initiële, door het Ministerie van Onderwijs, Cultuur en Wetenschappen erkende, hbo-opleiding hebben behaald. Sinds het uitvoeringsjaar 1993 bestrijkt de HBO-Monitor alle zeven hbo-sectoren: agrarisch (hao), pedagogisch (hpo), technisch (hto), economisch (heo), gezondheidszorg (hgzo), sociaal-agogisch (hsao) en kunst (kuo). Het betreffende studiejaar liep van 1 september 1993 tot 1 september 1994. De schriftelijke meting heeft tussen oktober 1996 en februari 1997 plaatsgevonden, hetgeen doorgaans zo'n anderhalf jaar na afstuderen is.

Op de sectorspecifieke voor het Kunstvakonderwijs na, zijn de vragenlijsten voor alle andere sectoren gelijk. Bij het opstellen van de vragenlijst voor het kunstvakonderwijs is bovendien uitgegaan van het principe van functionele vergelijkbaarheid. Hierdoor is onderlinge vergelijking en daarmee een landelijke rapportage voor het gehele hbo mogelijk. Over de volgende aspecten is in de HBO-Monitor informatie verzameld:

- persoonskenmerken (leeftijd, geslacht, etniciteit en samenstelling huishouden);

- gevolgde hbo-opleiding (studierichting, voltijd-/deeltijdstudie, diplomabezit en studieduur), vooropleiding, stage, werk- en bestuurlijke ervaring vóór afstuderen aan hbo;

eventuele vervolgopleiding(en) of cursus(sen) na (initiële) hbo-opleiding;

- maatschappelijke positie;

- kenmerken hoofdfunctie (beroep, verwervingskanaal, soort dienstverband en aanstelling, duur werkweek, functievereisten, leidinggeven en inkomen), organisatiekenmerken (branche, organisatiegrootte en vestigingsplaats) en kenmerken nevenfuncties;

- kwalitatieve aansluiting tussen gevolgde hbo-opleiding en beroepspraktijk (belang van 23 kwalificaties voor goede uitoefening functie en hoeveelheid aandacht voor deze aspecten tijdens hbo-opleiding), behoefte aan bijscholing, oordeel over onderwijsaspecten hbo-opleiding;

- zoekgedrag naar (ander) werk;

Voorjaar 1995 heeft de HBO-Raad de hogescholen benaderd om te participeren in de HBO-Monitor. In het kader van HBO-Monitor 1995 hebben 50 hogescholen bijna 30.000 afgestudeerden voor dit onderzoek laten benaderen. Dit betekent dat de HBO-Monitor inmiddels ongeveer tweederde van de totale uitstroom aan afgestudeerde hbo'ers dekt.

Deelname aan de HBO-Monitor hield voor de betreffende hogeschool in dat men na aanmelding en opgave van het aantal te benaderen afgestudeerden zorg diende te dragen voor de verzending van de - reeds vooraf gecodeerde - vragenlijsten, het aanleggen van een verzendadministratie, en het verzenden van een rappel aan de afgestudeerden die na ruim een maand nog geen ingevulde vragenlijst hadden geretourneerd aan DESAN. In het geval de respons na twee verzendingen nog te laag was, kon de hogeschool rond de jaarwisseling nog een derde verzending uitvoeren. Om de hogescholen bij de verzending 
behulpzaam te zijn hebben de hogescholen een handleiding ontvangen.

De hogeschool kon het verzenden van de vragenlijsten ook uitbesteden aan DESAN. De ervaring in de voorgaande jaren heeft namelijk geleerd dat het uitbesteden van deze werkzaamheden de hogeschool veel werk (en geld) bespaart. Bovendien kan centrale verzending de controle en daarmee de kwaliteit van de dataverzameling ten goede komen. Hogescholen die meedoen aan de centrale verzending kunnen volstaan met het aanleveren van het adressenbestand van de betreffende afgestudeerden. In 1995 zijn bijna 17.000 afgestudeerden via centrale verzending benaderd.

Tussen oktober 1995 en februari 1996 zijn de afgestudeerden aangeschreven. Hierbij is zowel van het laatst bekende studie-adres als het ouderlijk adres (voor zover bekend) gebruik gemaakt. Er hebben, afhankelijk van de respons, de beschikbaarheid van (meerdere) adresgegevens en de medewerking van hogescholen, maximaal drie verzendingen plaatsgevonden. Om de respons te verhogen zijn bij sommige hogescholen de afgestudeerden ook nog diverse malen telefonisch benaderd om de vragenlijst alsnog in te sturen. Eind februari 1996 is de inzendtermijn definitief gesloten. Vragenlijsten die later zijn ingestuurd konden niet meer in het onderzoeksbestand worden opgenomen.

In tabel 2.1 staat het overzicht van het resultaat van de dataverzameling. Er zijn in totaal 28.985 vragenlijsten uitgezet over de gediplomeerde uitstroom ${ }^{2}$ uit het studiejaar 1993/1994. Een deel (185) van deze vragenlijsten is door hogescholen die de verzending zelf verzorgden uiteindelijk ongebruikt geretourneerd, aangezien deze hogescholen vóóraf een te groot aantal afgestudeerden hadden opgegeven. Verder bleken 7 afgestudeerden inmiddels te zijn overleden. Deze twee groepen zijn achterwege gelaten bij de berekening van het responspercentage (de respons is derhalve gerelateerd aan 28.793 afgestudeerden).

Buiten de groep afgestudeerden die in het geheel niet gereageerd hebben (de nonrespons), kunnen de volgende categorieën worden onderscheiden:

- afgestudeerden waarvan de vragenlijst die naar het ouderlijk en/of studie-adres is gestuurd onbestelbaar retour is gekomen en waarvan de vragenlijst niet alsnog (via een ander adres) is binnengekomen;

- afgestudeerden die onbereikbaar bleken door (langdurige) ziekte, een (langdurig) verblijf in het buitenland (vredesmacht, au pair, buitenlandse studie e.d.);

- afgestudeerden die expliciet te kennen hebben gegeven niet deel te willen nemen aan het onderzoek.

Overigens bevat de non-respons groep ook een groot aantal afgestudeerden waarvan het huidige adres onbekend is en die derhalve niet bereikt konden worden. Het precieze aantal

2. Bij het kunstvakonderwijs konden de hogescholen ook de ongediplomeerden laten benaderen. Over deze gegevens is echter niet in de openbare landelijke rapportages gerapporteerd. 
is daarvan echter niet aan te geven. De groep 'onbestelbaar retour' vormt derhalve een onderschatting van het fenomeen 'adres onbekend'.

Tabel 2.1

Resultaat dataverzameling HBO-Monitor 1995 (gediplomeerden)

Resultaat dataverzameling

Totaal HBO

aantal afgestudeerden

Uitgezette vragenlijsten,

28.985

waarvan:

- teveel bestelde lijsten

- overleden

- vragenlijst onbestelbaar retour

7

- onbereikbaar door ziekte, verblijf buitenland e.d.

- expliciete weigering

51

- non-respons

12.237

Respons,

15.169

waarvan:

- na sluitingsdatum

- onverwerkbaar / niet onderzoekspopulatie (individuele cases)

Landelijk onderzoeksbestand:

14.569

Uit tabel 2.1 blijkt verder dat niet alle afgestudeerden die - op tijd - de vragenlijst hebben ingestuurd zijn opgenomen in het uiteindelijke (landelijk) onderzoeksbestand. De belangrijkste reden hiervoor is dat de hogescholen afgestudeerden hebben laten aanschrijven die niet tot de onderzochte populatie behoren. In de meeste gevallen gaat het dan om afgestudeerden die niet in het studiejaar 1993/1994 het diploma hebben behaald. Het gaat hier steeds om enkelingen en kleine groepen binnen een opleiding. Dit heeft met name te maken met het feit dat hogescholen het bestand vaak naar instroomjaar hebben ingericht (en ook zo hebben aangeleverd), in plaats van naar uitstroomjaar. In de vragenlijst is daarom een aantal controlevragen ingebouwd om hiervoor, indien nodig, te corrigeren. Daarnaast zijn sommige vragenlijsten te onvolledig ingevuld, waardoor een goede verwerking niet mogelijk was.

Tabel 2.2 toont voor iedere sector het responspercentage. Het responspercentage betreft het aantal responderende afgestudeerden gedeeld door het aantal daadwerkelijk benaderde afgestudeerden uit de betreffende lichting (x 100\%). Het responspercentage varieert van $34 \%$ voor de sector kunst tot $59 \%$ voor de sector gezondheidszorg. Voor het totale hbo bedraagt de respons $53 \%$. Met bijna 9.000 uitgezette vragenlijsten is de absolute deelname met name in de economische sector hoog. De technische sector komt met ruim 5.000 aanschrijvingen op de tweede plaats, terwijl de agrarische sector met bijna 1.700 lijsten de rij sluit. 
Tabel 2.2

Respons per sector (voltijd en deeltijd, gediplomeerden studiejaar 1993/1994)

\begin{tabular}{lll}
\hline Sector & Uitgezet & $\begin{array}{l}\text { Respons- } \\
\text { percentage }\end{array}$ \\
\hline Agrarisch & 1.685 & $57 \%$ \\
Pedagogisch & 3.254 & $53 \%$ \\
Technisch & 5.211 & $55 \%$ \\
Economisch & 8.684 & $54 \%$ \\
Gezondheidszorg & 2.857 & $59 \%$ \\
Sociaal-agogisch & 3.998 & $54 \%$ \\
Kunst & 3.104 & $34 \%$ \\
& & $53 \%$ \\
Totaal hbo & 28.793 & \\
\hline
\end{tabular}

Het is voor het onderzoek van belang om te weten of de respons representatief is. De respons moet namelijk een afspiegeling zijn van de totale (benaderde) populatie. In het geval de respons niet representatief is voor de totale groep afgestudeerden waarover men rapporteert, kan herweging van de gegevens plaatsvinden. Een eventuele ongelijke spreiding naar bijvoorbeeld opleiding of regio kan zo worden opgeheven (zie daarvoor hoofdstuk 3). Een herweging kan echter alleen maar worden uitgevoerd voor kenmerken die zowel voor de totale populatie als voor de onderzoekseenheden (de afgestudeerden die hebben gerespondeerd) bekend zijn.

Dit geldt bijvoorbeeld niet voor de variabele maatschappelijke positie. Deze is namelijk niet bekend voor de totale populatie, want dat wordt nu net met behulp van de HBO-Monitor onderzocht. Vanuit de onderzoeksliteratuur wordt er nogal eens op gewezen dat de respons onder werkloze afgestudeerden, vanwege eventuele gêne, lager zou kunnen zijn dan de respons onder de werkenden. Dit fenomeen wordt mogelijk gecompenseerd door het feit dat werkende afgestudeerden minder goed bereikbaar zijn, doordat zij voor hun baan zijn verhuisd. In het verleden is daarom een aantal keren een non-responsonderzoek uitgevoerd. Hieruit bleek dat de respons- en non-responsgroep niet significant van elkaar afweken op de daarin getoetste kenmerken geslacht, leeftijd en maatschappelijke positie.

In de periode van dataverzameling is ook de dataverwerking gestart. Nadat aan de hand van de op de vragenlijst voorgedrukte administratiecode de verzend- en responsadministratie is uitgevoerd, worden de antwoorden op de vragenlijsten gecodeerd en ingevoerd (de data-entry). Voor het coderen van de beroepen is gebruik gemaakt van de nieuwe Standaard Beroepenclassificatie die het Centraal Bureau voor de Statistiek (CBS) in 1992 heeft ontwikkeld. Hoewel de SBC '92 beter aansluit bij het hedendaagse beroepenveld is ook deze niet voldoende gedetailleerd voor schoolverlatersonderzoek en is derhalve voor de HBO-Monitor verder uitgebreid met hbo-specifieke beroepscategorieën. Voor het coderen van de branche waarin de afgestudeerde werkzaam is, is de in 1993 grondig 
herziene Standaard Bedrijfsindeling (SBI '93) van het CBS als uitgangspunt genomen. Deze is overigens ook uitgebreid met een aantal hbo-specifieke branches. Voor het coderen van de gevolgde hbo-opleiding, vooropleiding en eventuele vervolgopleiding(en) en cursus(sen) is een door het ROA en DESAN zelf ontwikkelde opleidingencodelijst gehanteerd, welke in grote lijnen gekoppeld kan worden aan de Standaard Onderwijsindeling (SOI) van het CBS. Ten slotte is de vestigingsplaats van de eventuele werkkring gecodeerd aan de hand van het Plaatsnamenregister (1995) van het CBS.

Nadat de gegevens van de vragenlijsten in een bestand zijn ingevoerd, is het daaruit resulterende onderzoeksbestand opgeschoond. Deze fase heet de data-cleaning. Overigens zijn al in het soft-ware pakket voor de data-entry vele grenswaarden en andere voorwaarden in verband met het invoeren van de vragenlijstgegevens opgenomen. De data-cleaning betrof het controleren en eventueel herstellen van de ingevoerde gegevens op basis van - tevoren vastgestelde - beslisregels. Grosso modo zijn de volgende controles uitgevoerd:

- mismatch data- en responsbestand;

- opgave door hogescholen van aantallen afgestudeerden naar opleiding, voltijd/deeltijdstudie, jaar van afstuderen en diplomabezit;

- verwijderen van onderzoekseenheden die niet tot populatie behoren (65 jaar of ouder, ongediplomeerd of in verkeerd studiejaar afgestudeerd) of die onvoldoende informatie hebben ingevuld;

- namen, labels, grenswaarden en routing van variabelen;

- 'anders, namelijk' - categorieën bij gesloten vragen hercoderen;

- inhoudelijke controle van persoonsgegevens, studieduur hbo-opleiding, vooropleiding, maatschappelijke positie, werkzame beroepsbevolking, personeelsomvang organisatie, nevenfuncties, inkomen en werkweek;

- aanmaken van nieuwe (samengestelde) variabelen ten behoeve van analyse en rapportages (bijvoorbeeld geregistreerde werkloosheid, beroepsbevolking, cursusdeelname).

Het hieruit resulterende onderzoeksbestand HBO-Monitor 1995 bevat uiteindelijk bijna 15.000 gediplomeerde onderzoekseenheden (zie ook tabel 2.1).

\section{Herweging naar landelijke cijfers}

Zoals in hoofdstuk 2 al is aangegeven kan in het onderzoek sprake zijn van een ongelijke spreiding naar opleiding en regio. Hiervoor zijn meerdere redenen aan te voeren. In de eerste plaats kan de deelname aan de HBO-Monitor ongelijk naar opleiding en regio zijn. ledere (faculteit van een) hogeschool bepaalt namelijk zelf of zij al dan niet in de HBOMonitor participeren. Daarnaast kan een ongelijke spreiding optreden doordat de afgestudeerden uit de ene opleiding of regio minder vaak hebben gerespondeerd dan de afgestudeerden uit andere opleidingen en regio's. 
In het landelijk rapport van HBO-Monitor 1995 worden ter gelegenheid van het vijfjarig bestaan van de HBO-Monitor de ontwikkelingen in deze gehele periode gepresenteerd. Ten behoeve hiervan zijn dit jaar ook de cijfers van HBO-monitor 1991 en 1992 herwogen met behulp van de zogenaamde "werktabellen" voor de statistiek van het hbo van het Centraal Bureau voor de Statistiek. Ook de resultaten uit het schoolverlatersonderzoek dat het Bureau Arbeidsmarktonderzoek STOAS in 1991 en 1992 onder de afgestudeerden van het hao heeft uitgevoerd, en dat grote gelijkenis vertoont met de HBO-Monitor, zijn aan de HBO-Monitor bestanden gekoppeld. Vorig jaar zijn de gegevens van zowel de HBOMonitor 1994 als 1993 al herwogen naar opleiding en (waar mogelijk en relevant) naar regio. Het bestand HBO-Monitor 1991-1995 betreft daarmee een compleet gewogen bestand over de periode $1991 \mathrm{t} / \mathrm{m} 1995$.

Voor deze herweging is gebruik gemaakt van het Centraal Register Inschrijvingen Hoger Onderwijs (CRIHO) van het Ministerie van Onderwijs, Cultuur en Wetenschappen (OCW). Het CRIHO bevat echter niet voldoende betrouwbare gegevens over het hoger agrarisch onderwijs. Hiervoor zijn de gegevens van het Ministerie van Landbouw, Natuurbeheer en Visserij (LaNVi) benut.

Ten eerste is op basis van het HBO-Monitor bestand de verdeling van het aantal afgestudeerden naar opleidingsrichting en regio vastgesteld. Op arbeidsmarktrelevante gronden betreft de variabele regio 'west' (Utrecht, Noord- en Zuid-Holland en Zeeland) en 'rest' (overige provincies) Nederland. Voor de herweging naar opleidingsrichting zijn de opleidingsclusters als uitgangspunt genomen zoals gehanteerd voor de landelijke informatie in de instellingsrapportages. De opleidingsclusters worden naar voltijd- en deeltijd onderscheiden indien in het onderzoeksbestand zowel het aantal voltijders als deeltijders minimaal 15 afgestudeerden bedraagt. In het geval een opleidingscluster in het onderzoeksbestand niet of met minder dan 15 afgestudeerden in alleen West-Nederland of alleen de overige provincies is vertegenwoordigd, is geen onderscheid naar regio gemaakt. Ook grote opleidingsclusters die relatief slecht zijn vertegenwoordigd in de HBO-Monitor (en bijgevolg een hoge weegfactor hebben) zijn niet naar regio onderverdeeld. De verdeling van de ongewogen aantallen afgestudeerden zijn per sector in tabel 3.1 afgebeeld.

Vervolgens zijn op basis van bovengenoemde databronnen de populatietotalen voor de opleidingsrichtingen, eventueel onderverdeeld naar regio, bepaald. Bij opleidingen die integraal aan de HBO-Monitor deelnemen is voor het bepalen van de populatie uitgegaan van het totaal aantal benaderde afgestudeerden. Een onderscheid naar regio is voor deze opleidingen achterwege gelaten. De ongewogen aantallen naar opleidingsrichting (en regio) uit het onderzoeksbestand zijn daarna zodanig met een weegfactor vermenigvuldigd dat het totaal aantal afgestudeerden gelijk is aan de populatietotalen per opleiding (en regio). Het resultaat van de herweging staat in tabel 3.2, waarbij is gesommeerd over de gewogen opleidingsrichtingen tot de zeven hbo-sectoren. 
Tabel 3.1

Aantallen afgestudeerden per sector in het ongewogen bestand voor HBO-Monitor 1995

Sector

ONGEWOGEN

1995

Agrarisch

Pedagogisch

1686

Technisch

2831

Economisch

4568

Gezondheidszorg

Sociaal-agogisch

2112

Kunst

Het ongewogen HBO-Monitor bestand bevat dus de gegevens zoals zij zijn verzameld, terwijl het gewogen bestand een representatieve afspiegeling vormt van de verdeling van de opleidingsrichtingen (en regio) in de Nederlandse populatie van afgestudeerden van het initiële hbo. Echter, wel voor zover de opleidingsrichting in de HBO-Monitor is vertegenwoordigd. Indien geen enkele hogeschool een bepaalde opleiding aan de HBO-Monitor heeft laten deelnemen kan over deze opleiding ook geen informatie worden verstrekt en uiteraard ook geen herweging plaatsvinden. Het totaalcijfer in de HBO-Monitor voor het gehele hbo is hierdoor echter wel iets lager dan de totale populatie op basis van de gegevens van beide ministeries.

De afgestudeerden van de voltijdse tweede graads docentopleidingen, die standaard in twee hoofdvakken de lesbevoegdheid hebben behaald, zijn in de HBO-Monitor slechts één keer aangeschreven. In het CRIHO wordt echter ieder vak waarin de afgestudeerde de lesbevoegdheid heeft behaald meegeteld. Voor deze 'dubbeltelling' in het CRIHO is bij de herweging gecorrigeerd, zodat deze afgestudeerden slechts éénmalig worden geteld. Bij andere opleidingen kon op voorhand met een mogelijke dubbele opleidingskwalificatie in het betreffende studiejaar geen rekening worden gehouden. De betreffende afgestudeerden zijn voor al deze opleidingen aangeschreven. Ook in het CRIHO zijn afgestudeerden met een dubbele kwalificatie meerdere keren geteld. Overigens komen dubbele kwalificaties behaald in één studiejaar, buiten de voltijdse tweede graads docentopleidingen, nauwelijks voor. Als hiervan al sprake is betreft het doorgaans meerdere specialisaties binnen één opleiding.

Tabel 3.2

Aantallen afgestudeerden per sector in het gewogen bestand voor HBO-Monitor 1995 
$\begin{array}{lr}\text { Pedagogisch } & 7679\end{array}$

$\begin{array}{lr}\text { Technisch } & 10334\end{array}$

Economisch 11220

$\begin{array}{ll}\text { Gezondheidszorg } & 5143\end{array}$

Sociaal-agogisch $\quad 6044$

$\begin{array}{ll}\text { Kunst } & 3210\end{array}$

\begin{tabular}{ll} 
Totaal hbo & 45314 \\
\hline
\end{tabular}

Bij het bepalen van de populatie-aantallen voor de opleidingsclusters bij de lerarenopleidingen zijn, in tegenstelling tot het principe in de andere sectoren, niet alleen de (combinaties van) vakken meegeteld die feitelijk in het onderzoeksbestand voorkomen, maar ook de populatieaantallen van alle andere (combinaties) van vakken die tot de onderscheiden clusters taal, maatschappij, exact en expressie behoren.

\section{Analyses}

\subsection{Factoranalyse}

De verschillende in de HBO-Monitor gemeten arbeidsmarktindicatoren zijn onderling sterk gecorreleerd. Deze gecorreleerde indicatoren meten blijkbaar een vergelijkbaar element van de arbeidsmarktpositie van de hbo'ers. Met behulp van een factoranalyse is onderzocht of de indicatoren te herleiden zijn tot één of enkele 'latente' variabelen die deze onderliggende elementen van de arbeidsmarktpositie zo goed mogelijk weergeven. Om tot zo robuust mogelijke resultaten te komen is de analyse uitgevoerd op het samengestelde bestand van HBO-Monitor 1991 tot en met 1995. De bij deze analyse gebruikte indicatoren voor de arbeidsmarktpositie zijn:

- Intredewerkloosheid $\leq 3$ maanden;

- Niet werkzoekend op het enquêtemoment;

- Baan op minimaal hbo-niveau;

- Baan in de eigen of een daaraan verwante richting;

- Vaste aanstelling;

- Full-time baan;

- Bruto-uurloon.

Om de indicatoren onderling zinvol te kunnen vergelijken zijn in eerste instantie de percentages per opleidingscluster berekend, behalve voor het bruto-uurloon waarvoor het gemiddelde is berekend. Vervolgens zijn de percentages en het gemiddelde uurloon allen gestandaardiseerd, dat wil zeggen getransformeerd tot variabelen waarvan het gemiddelde gelijk is aan 0 en de standaarddeviatie gelijk aan 1 .

Met behulp van factoranalyse is de correlatiematrix van deze zeven gestandaardiseerde 
arbeidsmarktindicatoren nader geanalyseerd. De gehanteerde factoranalyse-techniek is de principale componenten-analyse met varimax-rotatie en Kaiser-normalisatie. De uitkomsten van deze factoranalyse staan in tabel 4.1 .

Tabel 4.1

Uitkomsten van de factoranalyse

\begin{tabular}{lrr}
\hline Variabele & $\begin{array}{c}\text { Lading } \\
\text { Factor 1 }\end{array}$ & $\begin{array}{c}\text { Lading } \\
\text { Factor 2 }\end{array}$ \\
\hline Vaste baan & $\mathbf{0 , 5 1 1}$ & 0,234 \\
Baan op minimaal hbo-niveau & 0,150 & $\mathbf{0 , 8 0 8}$ \\
Baan in eigen/verwante richting & 0,142 & $\mathbf{0 , 7 6 9}$ \\
Niet werkloos op enquêtemoment & $\mathbf{0 , 7 5 1}$ & 0,191 \\
Niet langer dan drie maanden werkzoekend & $\mathbf{0 , 9 6 2}$ & 0,130 \\
Full-time werk & $\mathbf{0 , 3 9 1}$ & 0,001 \\
Hoogte bruto-uurloon & 0,067 & $\mathbf{0 , 4 7 2}$ \\
& & \\
\hline Eigenwaarde & 2,82 & $\mathbf{1 , 5 3}$ \\
Verklaarde variantie & $40,3 \%$ & $21,8 \%$ \\
\hline
\end{tabular}

De uitkomsten van de factoranalyse tonen aan dat er een tweetal factoren geëxtraheerd worden; te weten een factor met hoge ladingen op de indicatoren vaste baan, niet werkloos, zowel na drie maanden als op het enquêtemoment, en op de indicator full-time baan. Samenvattend kan deze factor gezien worden als een maatstaf voor de werkgelegenheid in ruime zin. Daarnaast laadt factor 2 vooral op de indicatoren betreffende het hebben van een baan op minimaal hbo-niveau en in de eigen of daaraan verwante richting en op de indicator bruto uurloon. Dit zijn allen indicatoren die duidelijk een maatstaf zijn voor de kwaliteit van het gevonden werk. Beide factoren tezamen verklaren $62 \%$ van de totale variantie.

\subsection{Typeringscriteria}

De twee in paragaaf 4.1 afgeleide factoren betreffende de arbeidsmarktpositie van de hboafgestudeerden zijn in het rapport van HBO-Monitor 1995 kwalitatief getypeerd per hbosector en per opleidingscluster. Deze typeringen zijn tot stand gekomen door middel van sommering van de standaardscores van de oorspronkelijke indicatoren per factor (zie voor de vaststelling van de oorspronkelijke indicatoren paragraaf 4.1). Deze somscores zijn vervolgens wederom gestandaardiseerd, zodat beide factoren waarden kennen met een gemiddelde van 0 en een standaarddeviatie van 1. Dankzij de standaardisatie is per sector/cluster de relatieve arbeidsmarktpositie ten opzichte van de arbeidsmarktpositie in de overige sectoren c.q. clusters bepaald.

Aangezien een belangrijke eigenschap van gestandaardiseerde variabelen is dat deze 
variabelen per definitie standaard-normaal verdeeld zijn (dus met gemiddelde 0 en standaarddeviatie 1), is de kansverdeling van de factorscores hierbij eveneens bekend. De kwalitatieve typeringen 'goed', 'gemiddeld' en 'matig' zijn vervolgens zodanig vastgesteld, zodat zowel de kans op een typering 'goed' als op 'matig' $30 \%$ is, en de typering 'gemiddeld' $40 \%$ kans op voorkomen heeft. De typering 'goed' wordt toegekend aan een factor met een waarde waarvan de overschrijdingskans kleiner dan $30 \%$ is, oftewel waarden van minimaal 0.53 (de kans dat een standaardnormaal verdeelde variabele groter dan 0.52 is, is namelijk $30 \%$ ). De typering 'gemiddeld' geldt die factoren, met waarden tussen -0.53 en +0.53 en de typering 'matig' wordt toegekend bij waarden lager dan -0.52 .

\subsection{Opzet regressie-analyses}

De in de HBO-Monitor in het rapport en supplement opgenomen tabellen en grafieken geven in de eerste plaats een goed inzicht in de verschillen in arbeidsmarktpositie tussen afgestudeerden van de diverse hbo-sectoren, -opleidingen en achtereenvolgende cohorten. Daarnaast bestaan er ook belangrijke verschillen tussen de afgestudeerden uit één opleiding of jaargang. Daarom geeft de HBO-Monitor tevens inzicht in de belangrijkste succes- en faalfactoren waardoor de ene hbo'er een betere arbeidsmarktpositie heeft dan de andere afgestudeerde (zie ook hoofdstuk 6 landelijk rapport HBO-Monitor 1995).

Alvorens de afgestudeerde hbo'ers de arbeidsmarkt betreden, hebben zij immers in hun leven al de nodige 'bagage' opgedaan. Aan de ene kant gaat het om persoonskenmerken, zoals leeftijd, geslacht, etniciteit en gezinssituatie. Aan de andere kant heeft deze 'bagage' betrekking op de kwalificaties die de hbo'ers al vóór het afstuderen hebben opgedaan. Het gaat hier niet alleen om formele onderwijskwalificaties, zoals de vooropleiding, de hboopleiding en de studieduur, maar ook om informele kwalificaties, zoals werkervaring en bestuurlijke ervaring. Daarnaast heeft het zoekgedrag en de wijze waarop de afgestudeerde de beroepsloopbaan heeft gestart invloed op de arbeidsmarktpositie op het moment van enquêteren. Ook het marktsegment waarop de afgestudeerde hbo'er terecht is gekomen vormt een gedeeltelijke verklaring voor het verschil in arbeidsmarktsucces. Bovendien kunnen verschillen in functiekenmerken, zoals het niveau van de functie en het al dan niet hebben van een leidinggevende positie, verschillen in bruto uurloon verklaren. De positie op de arbeidsmarkt, waaronder het inkomen, kan ten slotte van invloed zijn op het oordeel van de hbo'ers over de aansluiting tussen de door hen gevolgde hbo-opleiding en hun werkzaamheden en op het achteraf al dan niet tevreden zijn met de studiekeuze. Uiteraard zijn voor de afzonderlijke analyses alleen de relevante verklarende variabelen opgenomen. Zo is het voor de analyse van de kans op werk niet zinvol om baankenmerken in de analyse op te nemen.

Met behulp van multivariate analyses is nagegaan welke zelfstandige invloed persoons-, kwalificatie-, intrede-, marktsegment-, en functiekenmerken van individuele afgestudeerden op indicatoren van de arbeidsmarktpositie van hbo'ers uitoefenen. Waar mogelijk is de analyse uitgevoerd op het ongewogen bestand over alle cohorten, om ook het (netto) 
effect van mogelijke arbeidsmarktverschuivingen in de tijd te meten. Waren de variabelen niet voor alle jaargangen beschikbaar, dan is de analyse uitgevoerd op het ongewogen bestand over HBO-Monitor 1995.

De regressie-analyses betreffen de volgende indicatoren van de arbeidsmarktpositie van de hbo'ers, onderverdeeld naar 'maatschappelijke positie', 'werkkenmerken' en 'oordeel over de gevolgde hbo-opleiding'.

Maatschappelijke positie

- verder studeren (tabel B.1)

- kans op snel vinden van werk (tabel B.2)

- kans op het hebben van werk op het enquêtemoment (tabel B.3)

\section{Werkkenmerken}

- werkzaam in MKB (tabel B.4)

- vaste aanstelling (tabel B.5)

- full-time aanstelling (tabel B.6)

- functie op minimaal hbo-niveau (tabel B.7)

- functie in de eigen of een daaraan verwante richting (tabel B.8)

- leidinggevende functie (tabel B.9)

- bruto uurloon (tabel B.10)

Oordeel over gevolgde hbo-opleiding

- algemeen oordeel over aansluiting tussen hbo en werk (tabel B.11)

- achteraf dezelfde studiekeuze (tabel B.12)

De analyse over verder studeren laat zien welke kenmerken van afgestudeerden bepalend zijn voor het al dan niet verder studeren. Het gaat hier om reguliere (door het Ministerie van OCW bekostigde) vervolgstudies aan universiteit, hogeschool of andere onderwijsinstellingen. Andere vormen van scholing worden hierbij buiten beschouwing gelaten. Voor de schatting van de kans op werk zijn alleen de afgestudeerden geselecteerd die zich in de intredeperiode van september 1993 tot de maand van enquêteren hebben aangeboden op de arbeidsmarkt: zij hebben in die periode werk verricht en/of zijn - volgens eigen opgave werkzoekend geweest.

Met uitzondering van de analyse van het bruto uurloon, waarvoor een multipele regressie is uitgevoerd, zijn de overige analyses met behulp van logistische regressie geschat. Omdat deze afhankelijke dummy-variabelen steeds slechts twee categorieën kennen (een waarde ' 0 ' of ' 1 '), levert een normale regressie-analyse een aantal problemen op, waarvan vooral schending van de assumptie van lineariteit ernstige gevolgen heeft. Om dit probleem te ondervangen is logistische regressie toegepast. In bijlage 1 worden achtereenvolgens de te verklaren en verklarende variabelen opgesomd die in de analyses zijn gebruikt. Hierbij wordt de inhoud van de betreffende variabele kort aangeduid, evenals een beschrijving 
van de mogelijke waarden van deze variabele. In een groot aantal gevallen betreft het 'dummy'-variabelen. Daarbij is een aantal verklarende variabelen met een zogenaamde referentiecategorie opgenomen. De resultaten van de overige categorieën zijn dan gerelateerd aan deze referentiecategorie. De resultaten van de uitgevoerde multivariate analyses worden in paragraaf 4.5 kort omschreven staan verder weergegeven in tabel $1 \mathrm{t} / \mathrm{m}$ tabel 12 in bijlage 2.

Daarnaast is voor de berekening van het 'MKB-effect' een achttal regressies op het bestand HBO-Monitor 1995 opnieuw uitgevoerd, maar dan met als extra verklarende variabele het al dan niet werkzaam zijn in het midden- en kleinbedrijf. De verklarende variabelen omvang werkkring en het werkzaam zijn in de profit/non-profit sector hebben voor deze extra variabele plaats gemaakt. Onderstaande tabel bevat de coëfficiënten van het al dan niet werkzaam zijn in het MKB op dit achttal te verklaren variabelen, inclusief de standaardfout. Van significante effecten is sprake, wanneer de kans dat het gemeten effect op toeval berust, kleiner dan $5 \%$ is.

Tabel 4.2

Zelfstandige invloed MKB op baankenmerken

$\begin{array}{lll}\text { Baankenmerken } & \text { B } & \text { S.E. Sign. }\end{array}$

\begin{tabular}{|c|c|c|c|}
\hline Vaste aanstelling & 0,2545 & 0,0352 & * \\
\hline Full-time baan & $-0,0929$ & 0,0444 & * \\
\hline Baan op minimaal hbo-nivau & $-0,3634$ & 0,0365 & * \\
\hline Baan in eigen/verwante richting & $-0,4018$ & 0,0347 & * \\
\hline Baan waarvoor werkervaring is vereist & $-0,0175$ & 0,0319 & \\
\hline Leidinggevende baan & 0,2660 & 0,0380 & * \\
\hline Bruto uurloon & $-1,2574$ & 0,0782 & * \\
\hline Goede aansluiting opleiding-werk & $-0,0875$ & 0,0423 & * \\
\hline
\end{tabular}

${ }^{*}$ = significant effect op 5\%-niveau

\subsection{De referentie-hbo'er}

Om niet alleen iets te kunnen zeggen over de invloedsrichting maar ook over de grootte van de invloed van de onafhankelijke variabelen op de afhankelijke arbeidsmarktindicatoren, is deze invloed in de HBO-Monitor 1995 voor enkele indicatoren gekwantificeerd. Noodzakelijkerwijs is hierbij een referentie-hbo'er vastgesteld, waaraan de effecten gerelateerd zijn. Deze referentie-hbo'er bezit de volgende kenmerken:

\section{Cohort}

- afgestudeerd in jaargang 1993/1994 


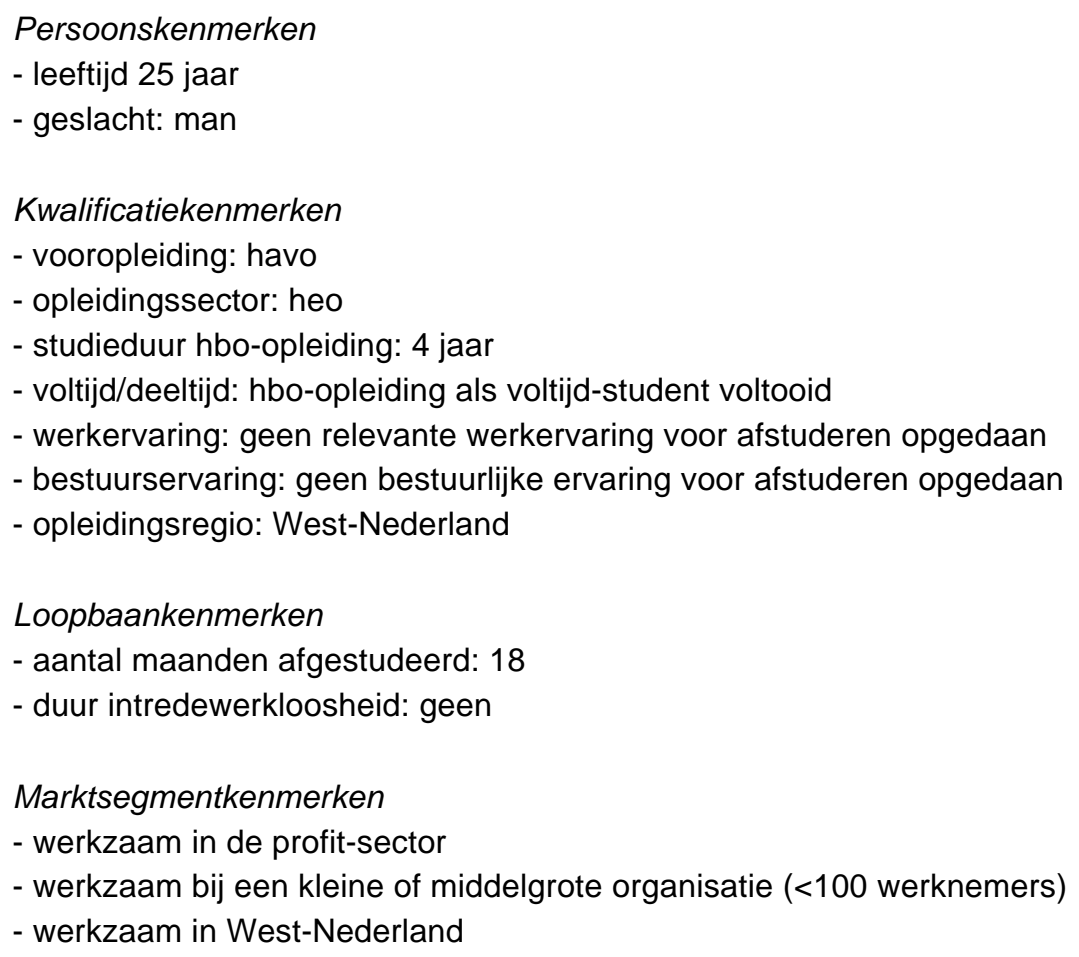

De berekening van de netto-effecten ten opzichte van de referentie-hbo'er is uitgevoerd voor de in paragraaf 4.1 genoemde arbeidsmarktindicatoren. Hiervoor is gebruik gemaakt van de resultaten uit de eerder besproken regressie-analyses. Met uitzondering van de indicator bruto-uurloon, betroffen dit resultaten van logistische regressies. De consequentie hiervan is dat voor de berekening van het marginale effect van de verklarende variabelen op de overige arbeidsmarktindicatoren, rekening dient te worden gehouden met alle overige effecten (coëfficiënten) van de regressie. De resultaten geven de procentuele marginale effecten weer van de verklarende variabelen op deze arbeidsmarktindicatoren (zie bijlage 2). Overigens wordt bij de verklarende duurvariabelen leeftijd, studieduur, afstudeerduur en duur intredewerkloosheid volstaan met het weergeven van de eventuele invloedsrichting. Het procentuele effect hoeft namelijk niet in gelijke mate respectievelijk toe of af te nemen. Verder is het marginale effect van de verklarende variabelen op het bruto uurloon weergegeven. Aangezien het bruto uurloon verklaard is met behulp van een lineaire regressie, zijn de marginale effecten hier gelijk aan de $\beta$-coëfficiënten. Bij alle indicatoren zijn overigens allleen marginale effecten weergegeven voorzover de verklarende variabele een significante invloed op de te verklaren indicator heeft. Dit betekent dat de kans dat er sprake is van een effect dat slechts op toeval is berust, hier hooguit $1 \%$ is.

\subsection{Resultaten regressie-analyses}

Resultaten samengevat 
In tabel 4.3 en 4.4 worden de resultaten van de regressie-analyses samengevat. Voor de technische specificaties wordt er verwezen naar de tabellen in bijlage 2 .

Tabel 4.3

Succesbepalende factoren bij werkzekerheid

Werkzekerheid

\begin{tabular}{|c|c|c|c|c|}
\hline & $\begin{array}{l}\text { bij intrede } \\
\leq 3 \text { mnd. } \\
\text { werk- } \\
\text { zoekend }\end{array}$ & $\begin{array}{l}\text { niet } \\
\text { werkloos } \\
\text { enquête- } \\
\text { moment }\end{array}$ & $\begin{array}{l}\text { vaste } \\
\text { baan }\end{array}$ & $\begin{array}{l}\text { full- } \\
\text { time } \\
\text { baan }\end{array}$ \\
\hline Referentie-hbo'er & $87 \%$ & $93 \%$ & $61 \%$ & $93 \%$ \\
\hline \multicolumn{5}{|l|}{ Meting(Cohort) } \\
\hline 1991(1989/1990) & $+4 \%$ & & $+11 \%$ & $+2 \%$ \\
\hline 1992(1990/1991) & & $-3 \%$ & $+8 \%$ & $+2 \%$ \\
\hline 1993(1991/1992) & & $-4 \%$ & $+7 \%$ & \\
\hline 1994(1992/1993) & $-2 \%$ & $-2 \%$ & $+3 \%$ & \\
\hline 1995(1993/1994) & ref & ref & ref & ref \\
\hline \multicolumn{5}{|c|}{ Persoonskenmerken } \\
\hline Leeftijd: ouder & - & - & & - \\
\hline Sekse: vrouw & & & & $-6 \%$ \\
\hline \multicolumn{5}{|c|}{ Kwalificatiekenmerken } \\
\hline \multicolumn{5}{|c|}{ Vooropleiding: } \\
\hline havo & ref & ref & ref & ref \\
\hline \multicolumn{5}{|l|}{ vwo } \\
\hline $\mathrm{mbo}$ & $+1 \%$ & $+1 \%$ & & $+1 \%$ \\
\hline hbo & & & & $-2 \%$ \\
\hline anders & & & $-5 \%$ & \\
\hline
\end{tabular}

Tabel 4.3 (vervolg)

Succesbepalende factoren bij werkzekerheid

Werkzekerheid

$\begin{array}{lllr}\begin{array}{l}\text { bij intrede } \\ \leq 3 \text { mnd. } \\ \text { werk- } \\ \text { zoekend }\end{array} & \begin{array}{l}\text { niet } \\ \text { werkloos } \\ \text { enquête- } \\ \text { moment }\end{array} & \begin{array}{l}\text { vaste } \\ \text { baan }\end{array} & \begin{array}{c}\text { full- } \\ \text { time } \\ \text { baan }\end{array} \\ & & & \\ & & -9 \% & -6 \% \\ -4 \% & & -3 \% & +4 \% \\ -3 \% & -1 \% & r e f & \text { ref } \\ r e f & \text { ref } & +11 \% & -11 \% \\ +3 \% & +2 \% & & \end{array}$




\begin{tabular}{|c|c|c|c|c|}
\hline hsao & $-5 \%$ & $-2 \%$ & & $-11 \%$ \\
\hline kuo & $-15 \%$ & $-6 \%$ & $-5 \%$ & $-12 \%$ \\
\hline Deeltijd-hbo & $+14 \%$ & $+5 \%$ & $+26 \%$ & $+1 \%$ \\
\hline Studieduur & - & - & - & - \\
\hline Werkervaring & $+6 \%$ & $+3 \%$ & $+4 \%$ & \\
\hline Bestuurlijke ervaring & $+1 \%$ & $+1 \%$ & & $+1 \%$ \\
\hline \multicolumn{5}{|l|}{ Regio opleiding/werk: } \\
\hline noord & $-7 \%$ & $-4 \%$ & & $-2 \%$ \\
\hline oost & $-5 \%$ & $-2 \%$ & $-3 \%$ & $-1 \%$ \\
\hline west & ref & ref & ref & ref \\
\hline zuid & $-4 \%$ & $-2 \%$ & & $+1 \%$ \\
\hline buitenland & & & $+16 \%$ & $+8 \%$ \\
\hline \multicolumn{5}{|l|}{ Loopbaankenmerken } \\
\hline Meer maanden afgestudeerd & - & + & + & \\
\hline Langere intredewerkloosheid & $x$ & $\mathrm{x}$ & - & - \\
\hline \multicolumn{5}{|l|}{ Marktsegmentkenmerken } \\
\hline Non-profit-sector & $\mathrm{x}$ & $\mathrm{x}$ & $-8 \%$ & $-3 \%$ \\
\hline Bedrijfsomvang: $\geq 100$ pers. & $x$ & $\mathrm{x}$ & & $+3 \%$ \\
\hline
\end{tabular}

$+=$ positief effect, - = negatief effect, $x=$ niet in analyse opgenomen, ref= referentiecategorie

In de analyse wordt nu eerst weergegeven wat de kans op bijvoorbeeld een vaste aanstelling is voor deze referentie-hbo'er. In het geval van de kans op een vaste aanstelling is dat $61 \%$ (zie tabel 4.3). Vervolgens wordt nagegaan wat er gebeurt wanneer één van de kenmerken van deze referentie-hbo'er verandert. Stel dat deze persoon een deeltijdopleiding had afgesloten in plaats van een voltijd-opleiding, met hoeveel procent zou de kans op een vaste aanstelling dan veranderen? Uit tabel $4.3 \mathrm{komt}$ naar voren dat in dat geval de kans op een vaste aanstelling met $26 \%$ toeneemt. Zo kan men ook de andere effecten interpreteren. Stel bijvoorbeeld dat de referentie-hbo'er niet een heo maar een hao-opleiding had afgerond, dan zou de kans op een vaste aanstelling met $9 \%$ toenemen. Op deze wijze worden de effecten van bijna alle variabelen uitgedrukt in percentages, ten opzichte van de referentie-hbo'er. Bij de analyse over het uurloon is het effect van een variabele uitgedrukt in guldens.

Tabel 4.4

Succesbepalende factoren bij kwaliteit van werk

kwaliteit van werk

$\begin{array}{lll}\text { baan op } & \text { baan in } & \text { hoogte } \\ \text { minimaal } & \text { eigen/verwante } & \text { bruto } \\ \text { hbo-niveau } & \text { richting } & \text { uurloon }\end{array}$

$\begin{array}{llll}\text { Referentie-hbo'er } & 77 \% & 64 \% & f 18,60^{*}\end{array}$

Meting (Cohort)

$+4 \%-\quad-f 0,70$


1992(1990/1991)

1993(1991/1992)

1994(1992/1993)

1995(1993/1994)

ref

$+7 \%$

Persoonskenmerken

Leeftijd: ouder

Sexe: vrouw

$-3 \%$

ref

Kwalificatiekenmerken

Vooropleiding:

havo

vwo

mbo

hbo

anders

Opleidingssector:

hao

hpo

hto

heo

hgzo

hsao

kuo

Deeltijd-hbo

Studieduur: langer

Werkervaring

Bestuurlijke ervaring

$\begin{array}{rrl}\text { ref } & \text { ref } & \text { ref } \\ -3 \% & +4 \% & \\ +14 \% & +8 \% & f 0,90 \\ +4 \% & & \\ -5 \% & & \\ +13 \% & +10 \% & \\ +8 \% & +19 \% & \text { ref } \\ \text { ref } & \text { ref } & +f 1,00 \\ -8 \% & +28 \% & \\ -4 \% & +6 \% & f 3,10 \\ -9 \% & +8 \% & f 0,30 \\ + & -6 \% & f 0,30\end{array}$

Tabel 4.4 (vervolg)

Succesbepalende factoren bij kwaliteit van werk

kwaliteit van werk

$\begin{array}{lll}\text { baan op } & \text { baan in } & \text { hoogte } \\ \text { minimaal } & \text { eigen/verwante } & \text { bruto } \\ \text { hbo-niveau } & \text { richting } & \text { uurloon }\end{array}$

\section{Regio werk}

noord

oost

west

zuid

buitenland

Loopbaankenmerken

Meer maanden afgestudeerd

Langere intredewerkloosheid $f 0,30$ (per jaar)

- $f 0,90$

0,90

$f 3,10$

$f 0,30$
$f 0,30$

bo-niveau

$\begin{array}{rrl} & & \\ & & -f 0,40 \\ \text { ref } & \text { ref } & \text { ref } 0,50 \\ & +4 \% & -f 0,50 \\ +7 \% & +6 \% & f 2,20\end{array}$


Marktsegmentkenmerken

Non-profit-sector

Functiekenmerken

Werkweek: minimaal 30 uur

vaste aanstelling

Baan op minimaal hbo-niveau

Baan in eigen/verwante richting

Leidinggevende baan

$\begin{array}{lll}\mathbf{x} & \mathbf{x} & -f 2,10 \\ \mathbf{x} & \mathbf{x} & f 0,80 \\ \mathbf{x} & \mathrm{x} & f 2,00 \\ \mathbf{x} & \mathbf{x} & f 0,40 \\ \mathbf{x} & \mathrm{x} & f 0,90\end{array}$

"Dit uurloon geldt voor de referentie hbo'er die parttime werk heeft ( $<30$ uur per week), in een tijdelijke, niet-leidinggevende functie, waarvoor niet minimaal hbo werd vereist en ook geen opleiding in de eigen of daaraan verwante richting

$+=$ positief effect, - = negatief effect, $x=$ niet in analyse opgenomen, ref $=$ referentiecategorie

De bespreking van de uitkomsten geschiedt als volgt. Allereerst worden de effecten besproken van het jaar van afstuderen op de verschillende indicatoren van arbeidsmarktsucces. Dan volgt een bespreking van de effecten van persoonskenmerken en kwalificatiekenmerken. In de daarop volgende paragrafen worden de effecten van achtereenvolgens de regio, de loopbaan, het marktsegment en de functiekenmerken behandeld.

\section{Invloed van jaar van afstuderen}

De cohorteffecten in tabel 4.3 weerspiegelen in de eerste plaats de conjuncturele ontwikkelingen in de jaren negentig, waarvan de hbo'ers, als starters op de arbeidsmarkt, direct de weerslag hebben ondervonden. Ten tijde van de korte maar hevige recessie, tussen 1992 en 1994, was de werkloosheid onder de hbo'ers in vergelijking met de referentiehbo'er tussen de $2 \%$ en $4 \%$ hoger. De ontwikkeling in de kans op een vaste baan is de afgelopen jaren steeds ongunstiger geworden: de arbeidsmarkt voor pas afgestudeerde hbo'ers is steeds verder geflexibiliseerd. De referentie-hbo'er uit de meting 1995 heeft maar liefst $11 \%$ minder kans op een vaste aanstelling dan de vergelijkbare afgestudeerden uit de meting 1991. Begin jaren negentig hadden de hbo'ers ook vaker een full-time baan, hetgeen eveneens een betere kwantitatieve aansluiting met zich meebracht.

Tabel 4.4 laat zien dat de kans op werk in de eigen of daaraan verwante richting ten opzichte van het referentiejaar 1995, in de voorafgaande jaren hoger lag; zo hadden de afgestudeerde hbo'ers uit de meting 1993 7\% meer kans op werk in de eigen richting dan de referentie-hbo'er uit de meting 1995. Wat betreft de kans op een baan op (minimaal) hbo-niveau en de hoogte van het bruto uurloon, hebben zich de afgelopen jaren geen (grote) significante verschillen voorgedaan wanneer wordt gecorrigeerd voor andere variabelen.

\section{Invloed persoonskenmerken}

\section{Leeftijd}


De werkgelegenheidssituatie van hbo'ers verslechtert op een aantal terreinen met het toenemen van de leeftijd waarop men het hbo-diploma heeft behaald. Dit geldt zowel voor de kans op -het snel vinden van- werk als het hebben van een full-time baan. Terwijl bij de kans op werk leeftijdsdiscriminatie mogelijk een rol speelt, lijkt dat bij het al dan niet hebben van een full-time baan minder het geval. Oudere hbo'ers geven, vanwege ondermeer gezinstaken, waarschijnlijk zelf vaker de voorkeur aan een part-time baan. Bovendien zijn de oudere hbo'ers mogelijk langer op zoek naar werk, omdat zij minder snel een baan accepteren. Zij hebben namelijk vaker een baan op minimaal hbo-niveau en hebben, wellicht mede daardoor, een hoger bruto uurloon $(+\mathrm{fl} 0,30$ per jaar).

\section{Sekse}

Waar het de werkgelegenheidssituatie betreft zijn er betrekkelijk weinig verschillen tussen mannen en vrouwen. Beide hebben eenzelfde kans om langdurig werkzoekend te zijn of om werkloos te zijn op het moment van enquête. Ook zijn er geen verschillen in de kans op een vaste aanstelling. Wel werken vrouwen beduidend vaker parttime (het verschil met de mannelijke referentie-hbo'er bedraagt 6\%), maar dit kan uiteraard een gevolg zijn van vrijwillige keuze. Of dat ook het geval is met de geconstateerde verschillen met betrekking tot de kwaliteit van het werk, is echter nog maar de vraag. Het is opvallend dat ook voor pas afgestudeerden geldt dat vrouwen 3\% minder kans hebben op werk op hbo-niveau en op werk in de eigen of daaraan verwante richting. Bovendien verdienen vrouwen 90 cent minder per uur dan mannen, ook wanneer rekening wordt gehouden met het feit dat ze minder vaak op hbo-niveau werkzaam zijn of minder vaak een leidinggevende functie hebben. Omgerekend naar een full-time baan van 40 uur per week betekent dit een verschil tussen beide seksen van bruto fl 1.870,- op jaarbasis. Op de arbeidsmarkt van recent afgestudeerde hbo'ers hebben mannen en vrouwen derhalve niet een gelijkwaardige marktpositie.

\section{Etniciteit}

Analyse op basis van het bestand HBO-Monitor 1995 toont aan dat allochtone hbo'ers minder kans hebben om (snel) werk te vinden, minder kans op een baan op minimaal hboniveau en eveneens minder kans op een baan in de eigen of een daaraan verwante richting. Etniciteit heeft geen (significante) invloed op de kans op het hebben van een vaste aanstelling en op de hoogte van het bruto uurloon. Al met al heeft de nu nog relatief kleine groep allochtonen, ook als zij een hbo-diploma hebben behaald, in veel opzichten een slechtere arbeidsmarktpositie dan autochtonen.

\section{Huishouden}

Dezelfde analyses op basis van het bestand van 1995 maken tevens duidelijk dat hbo'ers die getrouwd zijn of samenwonen een sterkere arbeidsmarktpositie hebben dan de alleenstaanden en thuiswonenden. Zo hebben de (gehuwd) samenwonenden een grotere kans op het (snel) vinden van werk, en/of een vaste aanstelling en/of een functie op minimaal hbo-niveau. Ook is hun bruto uurloon over het algemeen hoger. 


\section{Sociaal milieu}

Het opleidingsniveau van de beide ouders is ook van invloed op de arbeidsmarktpositie van de hbo'er. Als algemeen beeld komt naar voren dat het opleidingsniveau van de ouderen een negatief effect heeft op de werkgelegenheidskansen, maar een positief effect op de kwaliteit van werk.

\section{Invloed kwalificaties}

\section{Vooropleiding}

De hbo'ers die voorafgaand aan hun hbo-opleiding al een middelbare beroepsopleiding hebben voltooid, zijn in het voordeel ten opzichte van de overige hbo'ers wat betreft de kansen op werk. Zij hebben, ten opzichte van de referentie-hbo'er die havo als vooropleiding heeft, $1 \%$ meer kans om (snel) aan het werk te komen. Hbo'ers die al eerder een andere hbo-opleiding hebben afgerond werken weliswaar minder vaak in een full-time baan, doch hebben een relatief goede kwalitatieve aansluiting naar de arbeidsmarkt: zo heeft deze groep $14 \%$ meer kans op werk op tenminste hbo-niveau, is de kans op werk in de eigen of daaraan verwante richting $8 \%$ hoger en is hun gemiddeld bruto uurloon 90 cent hoger. Hbo'ers met mbo als vooropleiding werken ten slotte vaker onder hbo-niveau (-3\%), maar hebben ten opzichte van de referentie-hbo'er wel een grotere kans om in de eigen vakrichting te werken $(+4 \%)$.

\section{Opleidingssector hbo}

De arbeidsmarktkansen van hbo'ers verschillen sterk per opleidingssector. In vergelijking met het heo, de sector die als referentiecategorie voor de referentie-hbo'er is gekozen, is de werkgelegenheidssituatie voor met name de afgestudeerden van het kuo en in mindere mate die van het hsao, hto en hpo relatief zwak te noemen. Deze hbo'ers kennen een kleinere kans om (snel) werk te vinden. De afgestudeerden van het kuo, hto en hao hebben een verhoogde kans op een tijdelijke aanstelling. Daarentegen is de werkgelegenheidssituatie voor de hgzo'ers relatief gunstig, met uitzondering van de kans op full-time werk, dat voor de sectoren hpo, hgzo, hsao en kuo, de sectoren waar vrouwen in de meerderheid zijn, fors lager is. De verschillen tussen de sectoren in kans op werk op het eigen niveau en in de eigen richting zijn eveneens fors te noemen. Hpo'ers en hto'ers hebben met hun opleiding een goede uitgangspositie om een baan op minimaal hboniveau te vinden, in tegenstelling tot met name de hsao'ers die de grootste kans hebben om in hun functie onderbenut te worden. Ook onder de hao'ers en kuo'ers is het onderbenuttingspercentage relatief hoog. Werk in de eigen vakrichting is relatief vaak weggelegd voor hgzo'ers en hto'ers. Heo'ers werken verhoudingsgewijs vaak buiten de eigen of verwante vakrichting. Deze verschillen in de kwaliteit van werk zijn overigens niet terug te vinden in verschillen in uurloon; alleen de hgzo'ers verdienen per uur significant meer (+ 1 gulden bruto) dan de andere hbo'ers.

\section{Voltijd/deeltijd-hbo}

Degenen die het hbo in deeltijd doorlopen hebben, kennen een relatief goede kwantitatie- 
ve aansluiting: ten opzichte van de referentie-hbo'er, die een voltijd-opleiding heeft afgerond, hebben de deeltijders $14 \%$ meer kans om binnen drie maanden werk te hebben, $5 \%$ meer kans om op het moment van enquêteren niet werkloos te zijn, en maar liefst $26 \%$ meer kans op een vaste aanstelling. Deeltijd-hbo'ers zijn al vaak tijdens de studie werkzaam. De lagere kans voor deeltijd-hbo'ers op respectievelijk een baan op minimaal hboniveau $(-9 \%)$ en op een baan in de eigen richting $(-6 \%)$ toont aan dat velen van hen er echter (nog) niet in geslaagd zijn zich een functie te verwerven die past bij hun nieuwe hbo-diploma. Wel verdienen deeltijd-hbo'ers aanzienlijk meer dan voltijd-hbo'ers, namelijk fl 3,10 bruto extra per uur. Ook dit heeft te maken met het al langer werkzaam zijn.

\section{Studieduur}

De tijd dat de hbo'er over de opleiding heeft gedaan, is vooral van invloed op de arbeidsmarktpositie wat betreft de dimensie werkgelegenheid. Zowel de kans op het (snel) hebben van werk, op het hebben van vast werk en op het hebben van full-time werk is kleiner voor degenen die langer dan vier jaar, de studieduur van de referentie-hbo'er, over de hbo-opleiding heeft gedaan. Daarentegen neemt de kans op een baan op minimaal hboniveau toe bij een langere studieduur.

\section{Werk-/bestuurlijke ervaring}

Het hebben van -relevante- werkervaring verhoogt de kans om (snel) werk te vinden aanzienlijk: zo hebben de hbo'ers met een dergelijke ervaring $6 \%$ meer kans om binnen drie maanden werk te vinden. Ook verhoogt (relevante) werkervaring de kans op een vast contract $(+4 \%)$. Werkervaring heeft ook een positieve invloed op enkele indicatoren van de kwaliteit van werk: men vervult, ten opzichte van de referentie-hbo'er zonder dergelijke ervaring, $3 \%$ vaker een baan in de eigen of daaraan verwante vakrichting en verdienen daarnaast 30 cent bruto per uur extra. De hbo'ers die al voor afstuderen bestuurlijke ervaring hebben opgedaan hebben eveneens een hoger bruto uurloon van 30 cent. Bestuurlijke ervaring heeft daarnaast met name een positief effect op de kans op werk op minimaal hbo-niveau: namelijk $+5 \%$.

\section{Invloed regio}

\section{Opleidingsregio}

Ook het regio-effect is in de analyses opgenomen. Voor de analyses die betrekking hebben op de werkende afgestudeerden is de werkregio als verklarende variabele gehanteerd. Bij de twee andere analyses is de opleidingsregio in de analyse betrokken. De kans om (snel) werk te vinden verschilt per regio waar de hbo'er de opleiding heeft gevolgd. Degenen die in West-Nederland zijn afgestudeerd hebben meer kans op het (snel) vinden van werk dan de afgestudeerden uit de overige regio's.

\section{Werkregio}

De regio waar de hbo'ers werk vinden is ook van invloed op de andere indicatoren van de werkgelegenheidssituatie. In vergelijking met de referentie-hbo'er die werkzaam is in West- 
Nederland, hebben de werkende hbo'ers in Oost-Nederland 3\% minder kans op een vaste aanstelling, terwijl de hbo'er die in het buitenland werkt $16 \%$ meer kans heeft op een vaste baan. Verder blijkt uit de analyse dat de hbo'ers die in het Noorden of Oosten van het land werken, ten opzichte van de in het Westen werkzame referentie-hbo'er, minder vaak fulltime werken (respectievelijk - $2 \%$ en - $1 \%$ ); terwijl degenen die in het Zuiden werken (+1\%) of in het buitenland $(+8 \%)$ vaker een full-time baan hebben. Wat betreft de kwaliteit van werk zijn de volgende regio-effecten waargenomen. In het Zuiden van het land werken de hbo'ers vaker in een baan waarvoor de eigen of een daaraan verwante opleidingsrichting werd vereist $(+4 \%)$. In het Westen van het land zijn de bruto uurlonen circa 50 cent hoger; omgerekend naar een full-time baan ruim fl 1000,- op jaarbasis. Hbo'ers die werkzaam zijn in het buitenland kennen verhoudingsgewijs een goede kwaliteit van het werk: zij werken significant vaker op minimaal hbo-niveau $(+7 \%)$ en/of in de eigen of daaraan verwante richting $(+6 \%)$, beiden ten opzichte van de referentie-hbo'er. Ten slotte verdienen deze hbo'ers per uur bruto 2,20 gulden extra.

\section{Geografische mobiliteit}

Hbo'ers die buiten de regio waar zij de opleiding hebben gevolgd werk hebben gevonden, hebben een relatief goede arbeidsmarktpositie, zowel wat betreft de werkgelegenheid als ook wat betreft de kwaliteit van werk. Hbo'ers die voor het verkrijgen van werk geografisch mobiel gedrag vertonen, hebben namelijk vaker een vaste baan en werken tevens vaker full-time. Daarnaast werken zij vaker op minimaal hbo-niveau en verdienen ze met hun werkzaamheden een hoger uurloon.

\section{Invloed loopbaan}

\section{Afstudeerdatum}

Hoewel het in de analyses gaat om hbo'ers die zich gemiddeld anderhalf jaar op de arbeidsmarkt bevinden, kan deze verblijfsduur door verschillen in afstudeerdatum variëren van 1 tot 2 jaar. Degenen die al wat langer geleden het hbo-diploma hebben behaald, hebben een verhoogde kans op een vaste baan. Bovendien zijn ze op het moment van enquêteren minder vaak werkloos. Daar staat tegenover dat ze minder kans hebben om binnen drie maanden werk te hebben.

\section{Duur intredewerkloosheid}

Een negatieve invloed op de arbeidsmarktpositie van de hbo'ers, zowel wat betreft de werkgelegenheid als wat betreft de kwaliteit van werk, gaat uit van een langere intredewerkloosheid. Een langere zoektijd verlaagt de kans op een vaste aanstelling en op een full-time baan. Tevens verlaagt een langere intredewerkloosheid de kans op werk op minimaal hbo-niveau en op een baan in de eigen of daaraan verwante richting. Ten slotte ligt het bruto uurloon van degenen met langere zoektijd iets lager.

\section{Functieduur}

Analyses op basis van het bestand 1995 tonen aan dat hbo'ers die al langer in de baan 
werkzaam zijn, een verhoogde kans hebben op een vaste aanstelling. Het gemiddelde bruto uurloon ligt daarnaast ook hoger bij een al langere functieduur.

\section{Invloed marktsegment}

\section{Profit/non-profit sector}

De werkgelegenheid is voor de hbo'ers die werkzaam zijn in de non-profit sector ongunstiger dan voor de werkenden in de profit-sector. Zo heeft iemand die een functie in de nonprofit sector bekleedt, ten opzichte van de referentie-hbo'er die in de profit sector werkt, $8 \%$ minder kans op een vaste aanstelling en $3 \%$ minder kans op een full-time baan. De arbeidsmarktpositie voor deze groep werkenden voor wat betreft de kwaliteit van werk laat een minder éénduidig beeld zien: het bruto uurloon ligt gemiddeld 30 cent onder het niveau in de profit-sector. Echter, wat betreft het hebben van werk in de eigen of daaraan verwante richting hebben hbo'ers in de non-profit sector een aanzienlijk voordeel; zij hebben $21 \%$ meer kans op een dergelijke baan.

\section{Personeelsomvang werkkring}

Hbo'ers die een baan hebben gevonden bij een grote organisatie (een organisatie met minimaal honderd arbeidskrachten) hebben $3 \%$ meer kans op een full-time betrekking dan de referentie-hbo'er die bij een kleine(re) organisatie werkzaam is. Daarnaast verdienen degenen die in een grote organisatie werken per uur bruto 60 cent extra.

\section{Invloed functiekenmerken}

Tot slot is nagegaan welke invloed functiekenmerken uitoefenen op de hoogte van het bruto uurloon van de werkende hbo'ers. Hierbij wordt verondersteld dat deze functiekenmerken bepalend zijn voor het salaris (en doorgaans niet andersom). Het hebben van een vaste baan $(+f \mid 0,80)$, een baan op minimaal hbo-niveau $(+f l 2,00)$ en/of in de eigen of verwante richting $(+\mathrm{fl} 0,40)$, evenals het hebben van een leidinggevende functie $(+\mathrm{fl} 0,90)$ heeft een positieve invloed op het bruto uurloon van de werkende hbo'er. De resultaten van de analyse tonen verder aan dat degenen die een werkweek van minimaal 30 uur per week hebben, over het algemeen een lager uurloon hebben dan degenen met een minder lange werkweek. Het verschil bedraagt hierbij 2,10 gulden bruto per uur ${ }^{3}$.

\section{Conclusie}

Behalve verschillen in de kansen op werk en werkzekerheid, zijn er ook grote verschillen waar te nemen in de kwaliteit van de baan die afgestudeerde hbo'ers weten te bemachtigen. Er is een omvangrijke groep hbo'ers die snel na afstuderen een goed bij de opleiding

${ }^{3}$ Het geconstateerd effect wordt mogelijk mede veroorzaakt door de wijze waarop het bruto uurloon is bepaald. Hoew el de afgestudeerden uitdrukkelijk is gevraagd eventueel overwerk niet op te geven, hebben met name zelfstandigen en freelancers, werkweken van meer dan 40 uur opgegeven. Aangezien dit niet altijd overwerk hoeft te betreffen, kon hiervoor niet worden gecorrigeerd 
passende baan vindt; daarnaast bestaat een groep gediplomeerden met minder goede perspectieven, zij nemen na enige tijd zoeken genoegen met een baan die duidelijk minder goed aansluit bij het behaalde hbo-diploma.

Wie goede en wie minder goede perspectieven heeft op de arbeidsmarkt is lang niet alleen afhankelijk van kwalificatiekenmerken (hbo-sector, vooropleiding, studieduur, relevante ervaringen). Ook factoren als sekse, etniciteit en opleidings- en werkregio blijken de arbeidsmarktpositie van de hbo'er te beïnvloeden. 


\section{Bijlage 1 Overzicht gebruikte variabelen}

Overzicht B.1

Beschrijving van gebruikte variabelen

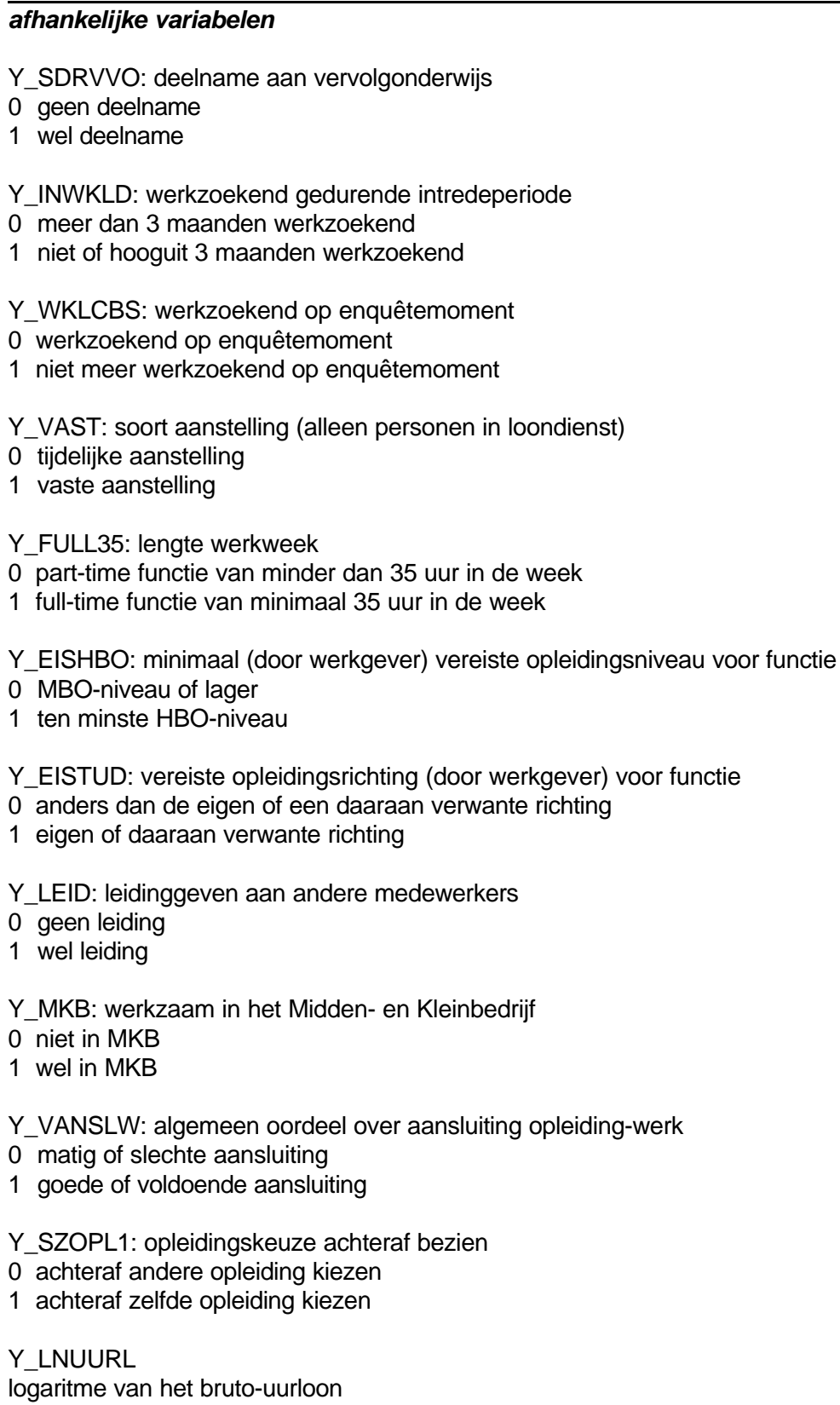


Y_UURLO

bruto-uurloon

\section{onafhankelijke dummy-variabelen met referentiecategorie}

cohort (referentie: afstudeerjaar 1993/1994)

M JR91: HBO-Monitor 1991

0 niet in studiejaar 1989/1990 afgestudeerd

1 wel in studiejaar 1989/1990 afgestudeerd

M JR92: HBO-Monitor 1992

0 niet in studiejaar 1990/1991 afgestudeerd

1 wel in studiejaar 1990/1991 afgestudeerd

M_JR93: HBO-Monitor 1993

0 niet in studiejaar 1991/1992 afgestudeerd

1 wel in studiejaar 1991/1992 afgestudeerd

M JR94: HBO-Monitor 1994

0 niet in studiejaar 1992/1993 afgestudeerd

1 wel in studiejaar 1992/1993 afgestudeerd

gezinssituatie / samenstelling huishouden (referentie: alleenstaand zonder kinderen)

M HHSMK: gehuwd/samenwonend met kinderen

0 niet

1 wel

M HHSZK: gehuwd/samenwonend zonder kind(eren)

0 niet

1 wel

M HHAMK: alleenstaand met kinderen

0 niet

1 wel

M HHTHU: thuiswonend

0 niet

1 wel

hoogst genoten vooropleiding (referentie: havo)

M VOP.VW: VWO als vooropleiding

0 niet

1 wel

M VOP.MB: MBO als vooropleiding

0 niet

1 wel

Overzicht B.1 (vervolg)

Beschrijving van gebruikte variabelen 
M_VOP.HB: HBO als vooropleiding

0 niet

1 wel

M_VOP.AN: andere vooropleiding genoten

0 niet

1 wel

hbo-sector (referentie: sector heo=economisch)

M_HAO: sector hao (agrarisch)

0 niet

1 wel

M_HPO: sector hpo (pedagogisch)

0 niet

1 wel

M_HTO: sector hto (technisch)

0 niet

1 wel

M_HGZO: sector hgzo (gezondheidszorg)

0 niet

1 wel

M_HSAO: sector hsao (sociaal-agogisch)

0 niet

1 wel

M_KUO: sector kuo (kunst)

0 niet

1 wel

M_HAO: sector hao (agrarisch)

0 niet

1 wel

regio hbo-opleiding (referentie: West-Nederland (Utrecht, Noord- en Zuid-Holland, Zeeland))

M_RGOPLN: Noord-Nederland (Groningen, Friesland, Drenthe)

0 niet

1 wel

M_RGOPLO: Oost-Nederland (Overijssel, Gelderland, Flevoland)

0 niet

1 wel

Overzicht B.1 (vervolg)

Beschrijving van gebruikte variabelen

M RGOPLZ: Zuid-Nederland (Noord-Brabant, Limburg)

0 niet 
1 wel

regio werkkring (referentie: West-Nederland (Utrecht, Noord- en Zuid-Holland, Zeeland))

M_RGWRKN: Noord-Nederland (Groningen, Friesland, Drenthe)

0 niet

1 wel

M_RGWRKO: Oost-Nederland (Overijssel, Gelderland, Flevoland)

0 niet

1 wel

M_RGWRKZ: Zuid-Nederland (Noord-Brabant, Limburg)

0 niet

1 wel

M_RGWRKB: buitenland

0 niet

1 wel

maatschappelijke positie op enquêtemoment (referentie: betaald werk)

M_STUDIE: studie

0 niet

1 wel

M WZOEK: werkzoekend

0 niet

1 wel

M_ANSITU: andere situatie

0 niet

1 wel

aard van de aanstelling (referentie: geen arbeidscontract)

M_SNTIJD: tijdelijk contract

0 niet

1 wel

M_SNVAST: vast contract

0 niet

1 wel

overige onafhankelijke variabelen (zonder referentiecategorie)

M_LEEFT: leeftijd (in jaren) op 31 december van enquêtejaar,

waarbij leeftijd beneden de 22 jaar op 22 en leeftijd vanaf 50 jaar op 50 is vastgesteld

Overzicht B.1 (vervolg)

Beschrijving van gebruikte variabelen

M SEXE: geslacht

0 man

1 vrouw 
M_ETNIC: etniciteit

0 rekent zichzelf tot een niet-Nederlandse bevolkingsgroep

1 rekent zichzelf tot Nederlandse bevolkingsgroep

M_VT_DT: voltijd-/deeltijdstudent aan hbo-opleiding

0 voltijd

1 deeltijd

M_STJR: netto studieduur hbo-opleiding (in jaren), waarbij studieduur vanaf 6 jaar op 6 is vastgesteld;

bij bepaling netto studieduur is rekening gehouden met eventuele studie-onderbreking

M_WRKERV(tbv regressies op HBO-Monitor '91-'95): voor vakgebied relevante (on)betaalde werkervaring vóór afstuderen aan hbo

0 wel werkervaring

1 geen werkervaring

M_WRKERV(tbv regressies op HBO-Monitor 1995): voor vakgebied relevante (on)betaalde werkervaring vóór afstuderen aan hbo

0 geen werkervaring

1 wel werkervaring

M_BSTERV: vóór afstuderen aan hbo-opleiding bestuurlijke ervaring opgedaan

0 geen bestuurlijke ervaring

1 wel bestuurlijke ervaring

M SZOPL1: achteraf bezien opnieuw hbo-opleiding kiezen?

0 nee

1 ja

M VANSLW: algemeen oordeel over aansluiting opleiding-werk

0 matig of slechte aansluiting

1 goede of voldoende aansluiting

M_AFSTDR: aantal maanden dat men is afgestudeerd op moment van enquêteren (in maanden)

M INWKLD(tbv. regressies op HBO-Monitor 1995): werkloosheidsduur gedurende intredeperiode

0 meer dan 3 maanden werkzoekend

1 niet of hooguit 3 maanden werkzoekend

M INWKLD(tbv. regressies op HBO-Monitor '91-'95): werkloosheidsduur in maanden gedurende intredeperiode

M_VBTMND: aantal maanden dat men in huidige functie werkzaam is (incl. eventuele periode vóór afstuderen aan hbo)

Overzicht B.1 (vervolg)

Beschrijving van gebruikte variabelen

M GEOMOB: geografische mobiliteit (vergelijking provincie werkkring en provincie hogeschool)

0 niet geografisch mobiel (werkzaam in zelfde of aangrenzende provincie)

1 wel geografisch mobiel (werkzaam in overige provincies of buitenland)

M NONPRF: werkzaam in profit / non-profit-sector

0 profit-sector 
1 non-profit-sector

M_OMVANG: personeelsomvang werkkring (aantal werknemers van totale concern in Nederland)

0 klein-/middelgroot bedrijf (1-99 personen)

1 grootbedrijf (100 personen of meer)

M_CAD30U: lengte werkweek (excl. eventuele nevenfunctie)

0 minder dan 30 uur per week

1 ten minste 30 uur per week

M_VAST: soort aanstelling (alleen personen in loondienst)

0 tijdelijke aanstelling

1 vaste aanstelling

M_EISHBO: voor functie (door werkgever) minimaal vereiste opleidingsniveau

0 MBO-niveau of lager

1 ten minste HBO-niveau

M_EISTUD: voor functie (door werkgever) vereiste opleidingsrichting

0 geen specifieke of andere dan gevolgde opleidingsrichting

1 eigen of verwante opleidingsrichting

M_EISERV: voor functie (door werkgever) vereiste werkervaring

0 niet

1 wel

M_LEID: leidinggevende functie

0 niet

1 wel

M_INKMND: bruto maandinkomen (in guldens; excl. neveninkomsten)

M_NEVEN: werkzaam in nevenfunctie (naast hoofdfunctie)

0 niet

1 wel

M_SMANIV: hoogst behaalde opleidingsniveau van de moeder

1 basisonderwijs

2 lagere beroepsopleiding, MAVO of MULO

3 HAVO, VWO, HBS, Gymnasium of MBO

$4 \mathrm{HBO}$ of universitair onderwijs

Overzicht B.1 (vervolg)

Beschrijving van gebruikte variabelen

M SVANIV: hoogst behaalde opleidingsniveau van de vader

1 basisonderwijs

2 lagere beroepsopleiding, MAVO of MULO

3 HAVO, VWO, HBS, Gymnasium of MBO

$4 \mathrm{HBO}$ of universitair onderwijs 


\section{Bijlage 2 Overzicht resultaten regressie-analyses}

Tabel B.1

Kans op verder studeren (variabele: Y_SDRVVO) o.b.v. gegevens HBO-Monitor 1995 (cohort 1993/1994)

\begin{tabular}{|c|c|c|c|}
\hline Variabele & B & S.E. & Sign. \\
\hline M LEEFT & $-0,0689$ & 0,0047 & * \\
\hline M־̄HHSMK & $-0,6705$ & 0,0565 & * \\
\hline M HHSZK & -1.0787 & 0.0304 & * \\
\hline M HHAMK & $-0,4016$ & 0,1302 & * \\
\hline M HHTHU & $-0,7610$ & 0,0344 & * \\
\hline M_SEXE & $-0,2588$ & 0,0294 & * \\
\hline METNIC & $-0,4759$ & 0,0757 & * \\
\hline M_VOP.VW & $-0,1460$ & 0,0323 & * \\
\hline M VOP.MB & $-0,5110$ & 0,0346 & * \\
\hline$M^{-}$VOP.HB & $-0,6162$ & 0,0635 & * \\
\hline M VOP.AN & $-0,8666$ & 0,0817 & * \\
\hline $\mathrm{MHAO}$ & $-0,2495$ & 0,0655 & * \\
\hline M HPO & $-0,1130$ & 0,0414 & * \\
\hline $\mathrm{M}$ HTO & $-0,3777$ & 0,0360 & * \\
\hline M_HGZO & $-0,8482$ & 0,0521 & * \\
\hline $\mathrm{M}$ HSAO & $-0,6190$ & 0,0470 & * \\
\hline M_KUO & $-0,7893$ & 0,0609 & * \\
\hline M VT DT & 0,2870 & 0.0542 & * \\
\hline M STJR & $-0,1633$ & 0,0150 & * \\
\hline M_AFSTDR & $-0,0360$ & 0,0046 & * \\
\hline M_WRKERV & $-0,0177$ & 0,0270 & \\
\hline M_BSTERV & 0,1850 & 0,0286 & * \\
\hline M RGOPLN & $-0,0194$ & 0,0525 & \\
\hline M_RGOPLO & 0,0394 & 0,0338 & \\
\hline M RGOPLZ & $-0,0099$ & 0,0310 & \\
\hline M_SZOPL1 & 0,0114 & 0,0300 & \\
\hline M SVANIV & 0.0696 & 0,0154 & * \\
\hline M SMANIV & 0,0515 & 0,0173 & * \\
\hline Constant & 3,3318 & 0,1707 & * \\
\hline
\end{tabular}

${ }^{*}$ = significant op 5\%-niveau

$\mathrm{N}=12.737$ (ongewogen aantal) 
Tabel B.2a

Kans op snel hebben van betaald werk (variabele: Y_INWKLD) o.b.v. gegevens HBO-Monitor 1995 (cohort 1993/1994)

\begin{tabular}{|c|c|c|c|}
\hline Variabele & B & S.E. & Sign. \\
\hline M_LEEFT & $-0,0829$ & 0,0048 & * \\
\hline M_HHSMK & 0,7817 & 0,0711 & * \\
\hline M-HHSZK & 0,4115 & 0,0367 & * \\
\hline M-HHAMK & 0,0396 & 0,1422 & \\
\hline M_HHTHU & $-0,0955$ & 0,0425 & * \\
\hline M_SEXE & 0,1039 & 0,0359 & * \\
\hline M_ETNIC & 0,4606 & 0,0885 & * \\
\hline M_VOP.VW & 0,0122 & 0,0408 & \\
\hline M_VOP.MB & 0,0718 & 0,0411 & \\
\hline M_VOP.HB & $-0,2075$ & 0,0721 & * \\
\hline M_VOP.AN & $-0,0221$ & 0,0825 & \\
\hline M_HAO & $-0,1498$ & 0,0823 & \\
\hline $\mathrm{M}^{-} \mathrm{HPO}$ & $-0,3045$ & 0,0533 & * \\
\hline M_HTO & $-0,1880$ & 0,0456 & * \\
\hline M_HGZO & 0,4357 & 0,0716 & * \\
\hline M_HSAO & $-0,5537$ & 0,0552 & * \\
\hline M_KUO & $-0,9352$ & 0,0607 & * \\
\hline M_VT_DT & 1,0637 & 0,0696 & * \\
\hline M_STJR & $-0,1360$ & 0,0176 & * \\
\hline M_AFSTDR & $-0,0394$ & 0,0052 & * \\
\hline M_WRKERV & 0,6065 & 0,0341 & * \\
\hline M_BSTERV & 0,2021 & 0,0369 & * \\
\hline M_RGOPLN & $-0,8088$ & 0,0570 & * \\
\hline M_RGOPLO & $-0,3916$ & 0,0408 & * \\
\hline M_RGOPLZ & $-0,2254$ & 0,0385 & * \\
\hline M_SZOPL1 & 0,0020 & 0,0001 & * \\
\hline M_SVANIV & $-0,0782$ & 0,0186 & * \\
\hline M_SMANIV & $-0,0171$ & 0,0210 & \\
\hline Constant & $-14,4258$ & 1,2744 & * \\
\hline
\end{tabular}

* = significant op 5\%-niveau

$\mathrm{N}=11.691$ (ongewogen aantal) 
Tabel B.2b

Kans op snel hebben van betaald werk (variabele: Y INWKLD) o.b.v. gegevens HBO-Monitor 1991-1995 (cohorten 1989/1990 t/m 1993/1994)

\begin{tabular}{|c|c|c|c|c|c|}
\hline Variabele & B & S.E. & Significant & Norm & $\begin{array}{l}\text { Procentueel } \\
\text { verschil t.o.v. } \\
\text { norm }\end{array}$ \\
\hline
\end{tabular}

\begin{tabular}{|c|c|c|c|c|c|}
\hline M_JR91 & 0,3606 & 0,0430 & * & 0 & $+4,1 \%$ \\
\hline M_JR92 & 0,0420 & 0,0404 & & 0 & \\
\hline M_JR93 & $-0,0420$ & 0,0366 & & 0 & \\
\hline M_JR94 & $-0,1991$ & 0,0363 & * & 0 & $+2,3 \%$ \\
\hline M_LEEFT & $-0,0643$ & 0,0041 & * & 25 & - \\
\hline M_SEXE & 0,0018 & 0,0291 & & 0 & \\
\hline M_VOP.VW & $-0,0363$ & 0,0325 & & 0 & \\
\hline M_VOP.MB & 0,0920 & 0,0347 & * & 0 & $+1,1 \%$ \\
\hline M_VOP.HB & $-0,0549$ & 0,0676 & & 0 & \\
\hline M_VOP.AN & $-0,1508$ & 0,0724 & & 0 & \\
\hline M_HAO & $-0,0597$ & 0,0573 & & 0 & \\
\hline M_HPO & $-0,3067$ & 0,0465 & * & 0 & $-3,5 \%$ \\
\hline M_HTO & $-0,2568$ & 0,0374 & * & 0 & $-3,0 \%$ \\
\hline M_HGZO & 0,2367 & 0,0500 & * & 0 & $+2,7 \%$ \\
\hline M_HSAO & $-0,4769$ & 0,0448 & * & 0 & $-5,5 \%$ \\
\hline M_KUO & $-1,2899$ & 0,0525 & * & 0 & $-14,9 \%$ \\
\hline M_VT_DT & 1,2251 & 0,0634 & * & 0 & $+14,1 \%$ \\
\hline M_STJR & $-0,2231$ & 0,0156 & * & 4 & - \\
\hline M_AFSTDR & $-0,0259$ & 0,0045 & * & 18 & - \\
\hline M_WRKERV & $-0,4909$ & 0,0284 & * & 1 & $-5,7 \%$ \\
\hline M_BSTERV & 0,1075 & 0,0287 & * & 0 & $+1,2 \%$ \\
\hline M_RGOPLN & $-0,5968$ & 0,0432 & * & 0 & $-6,9 \%$ \\
\hline M_RGOPLO & $-0,4105$ & 0,0328 & * & 0 & $-4,7 \%$ \\
\hline M_RGOPLZ & $-0,3164$ & 0,0322 & * & 0 & $-3,6 \%$ \\
\hline Constant & 5,3332 & 0,1444 & * & 1 & \\
\hline
\end{tabular}

* = significant op 1\%-niveau

$\mathrm{N}=51.004$ (ongewogen aantal) 
Tabel B.3

Kans op hebben van betaald werk op enquêtemoment (variabele: Y_WKLCBS) o.b.v. gegevens HBOMonitor 1991-1995 (cohorten 1989/1990 t/m 1993/1994)

\begin{tabular}{|c|c|c|c|c|c|}
\hline Variabele & B & S.E. & Sign. & Norm & $\begin{array}{l}\% \text {-verschil } \\
\text { t.o.v. norm }\end{array}$ \\
\hline M_JR91 & $-0,0056$ & 0,0635 & & 0 & \\
\hline M_JR92 & $-0,5381$ & 0,0568 & * & 0 & $-3,2 \%$ \\
\hline M_JR93 & $-0,6628$ & 0,0515 & * & 0 & $-4,1 \%$ \\
\hline M_JR94 & $-0,3971$ & 0,0534 & * & 0 & $-2,4 \%$ \\
\hline M LEEEFT & $-0,0344$ & 0,0058 & * & 25 & - \\
\hline M_SEXE & 0,3429 & 0,0401 & * & 0 & $+2,1 \%$ \\
\hline M_VOP.VW & 0,0741 & 0,0450 & & 0 & \\
\hline M_VOP.MB & 0,1608 & 0,0470 & * & 0 & $+1,0 \%$ \\
\hline M_VOP.HB & $-0,1606$ & 0,0912 & & 0 & \\
\hline M_VOP.AN & $-0,2501$ & 0,0969 & * & 0 & $-1,5 \%$ \\
\hline $\mathrm{M} \_\mathrm{HAO}$ & $-0,0118$ & 0,0753 & & 0 & \\
\hline M_HPO & $-0,0347$ & 0,0675 & & 0 & \\
\hline M_HTO & $-0,2182$ & 0,0493 & * & 0 & $-1,3 \%$ \\
\hline $\mathrm{M}^{-} \mathrm{HGZO}$ & 0,3218 & 0,0743 & * & 0 & $+2,0 \%$ \\
\hline $\mathrm{M} \mathrm{HSAO}$ & $-0,4062$ & 0,0621 & * & 0 & $-2,5 \%$ \\
\hline M_KUO & $-1,0129$ & 0,0732 & * & 0 & $-6,2 \%$ \\
\hline M_VT_DT & 0,7990 & 0,0852 & * & 0 & $+4,9 \%$ \\
\hline M_STJR & $-0,1967$ & 0,0212 & * & 4 & - \\
\hline M_AFSTDR & 0,0598 & 0,0071 & * & 18 & + \\
\hline M_WRKERV & $-0,5280$ & 0,0400 & * & 1 & $-3,2 \%$ \\
\hline M_BSTERV & 0,1291 & 0,0394 & * & 0 & $+0,8 \%$ \\
\hline M_RGOPLN & $-0,6149$ & 0,0568 & * & 0 & $-3,8 \%$ \\
\hline $\mathrm{M}^{-} \mathrm{RGOPLO}$ & $-0,3947$ & 0,0454 & * & 0 & $-2,4 \%$ \\
\hline M_RGOPLZ & $-0,2500$ & 0,0449 & * & 0 & $-1,5 \%$ \\
\hline Cōnstant & 3,7548 & 0,2068 & * & 1 & \\
\hline
\end{tabular}

${ }^{*}=$ significant op 1\%-niveau

$\mathrm{N}=46.773$ (ongewogen aantal) 
Tabel B.4

Kans om werkzaam te zijn in het Midden- en Klein Bedrijf (variabele: Y_MKB) o.b.v. gegevens HBOMonitor 1995 (cohort 1993/1994)

\begin{tabular}{|c|c|c|c|}
\hline Variabele & $B$ & S.E. & Sign. \\
\hline M_LEEFT & $-0,0035$ & 0,0056 & \\
\hline M_HHSMK & $-0,4125$ & 0,0745 & * \\
\hline M_HHSZK & 0,0655 & 0,0371 & \\
\hline M_HHAMK & 0,4382 & 0,1652 & * \\
\hline M_HHTHU & 0,1246 & 0,0441 & * \\
\hline M_SEXE & $-0,2507$ & 0,0351 & * \\
\hline M_ETNIC & $-0,2490$ & 0,0984 & * \\
\hline M_VOP.VW & 0,1756 & 0,0407 & * \\
\hline M_VOP.MB & 0,1543 & 0,0409 & * \\
\hline M_VOP.HB & 0,0732 & 0,0795 & \\
\hline M_VOP.AN & 0,2544 & 0,0906 & * \\
\hline M_HAO & $-0,0754$ & 0,0748 & \\
\hline M_HPO & $-1,5686$ & 0,0628 & * \\
\hline M_HTO & $-0,1446$ & 0,0384 & * \\
\hline M_HGZO & $-3,0171$ & 0,1263 & * \\
\hline M_HSAO & $-1,2131$ & 0,0597 & * \\
\hline M_KUO & 1,5532 & 0,0658 & * \\
\hline M_STJR & $-0,0918$ & 0,0177 & * \\
\hline M_AFSTDR & $-4,1 E-05$ & 0,0052 & \\
\hline M_WRKERV & 0,0713 & 0,0324 & * \\
\hline M_BSTERV & 0,0330 & 0,0344 & \\
\hline M_VT_DT & $-0,3585$ & 0,0647 & * \\
\hline M_RGOPLN & 0,1581 & 0,0642 & * \\
\hline M_RGOPLO & $-0,1349$ & 0,0444 & * \\
\hline M_RGOPLZ & 0,0107 & 0,0360 & \\
\hline M_INWKLD & $-0,0358$ & 0,0432 & \\
\hline M_GEOMOB & $-0,1842$ & 0,0447 & * \\
\hline M_SVANIV & $-0,0072$ & 0,0186 & \\
\hline M_SMANIV & 0,0825 & 0,0216 & * \\
\hline Constant & $-0,8411$ & 0,2124 & * \\
\hline
\end{tabular}

${ }^{*}=$ significant op $5 \%$-niveau

$\mathrm{N}=9.689$ (ongewogen aantal) 
Tabel B.5a

Kans op vaste baan (variabele: Y_VAST) o.b.v. gegevens HBO-Monitor 1995 (cohort 1993/1994)

\begin{tabular}{|c|c|c|c|}
\hline Variabele & B & S.E. & Sign. \\
\hline M_LEEFT & $-0,0214$ & 0,0055 & * \\
\hline M_HHSMK & 0,4685 & 0,0725 & * \\
\hline M_HHSZK & 0,2224 & 0,0351 & * \\
\hline M_HHAMK & $-0,1192$ & 0,1601 & \\
\hline M_HHTHU & $-0,0821$ & 0,0424 & \\
\hline M_SEXE & 0,0464 & 0,0348 & \\
\hline M_ETNIC & $-0,0291$ & 0,1053 & \\
\hline$M^{-}$VOP.VW & $-0,0252$ & 0,0389 & \\
\hline M_VOP.MB & $-0,0462$ & 0,0391 & \\
\hline M_VOP.HB & $-0,1448$ & 0,0769 & \\
\hline M_VOP.AN & $-0,2939$ & 0,0875 & * \\
\hline $\mathrm{M}-\mathrm{HAO}$ & $-0,3431$ & 0,0802 & * \\
\hline M_HPO & $-0,0167$ & 0,0568 & \\
\hline M_HTO & $-0,1177$ & 0,0407 & * \\
\hline M_HGZO & 0,5397 & 0,0626 & * \\
\hline M_HSAO & $-0,0330$ & 0,0549 & \\
\hline M_KUO & $-0,6367$ & 0,0875 & * \\
\hline M_VT_DT & 0,5103 & 0,0649 & * \\
\hline M_STJR & $-0,1067$ & 0,0178 & * \\
\hline M_AFSTDR & 0,0195 & 0,0052 & * \\
\hline$M^{-}{ }^{-} I N W K L D$ & 0,6614 & 0,0428 & * \\
\hline M_WRKERV & 0,1272 & 0,0309 & * \\
\hline M_BSTERV & 0,0391 & 0,0340 & \\
\hline M_RGWRKN & $-0,1341$ & 0,0695 & \\
\hline M_RGWRKO & $-0,1598$ & 0,0403 & * \\
\hline M_RGWRKZ & $-0,0005$ & 0,0354 & \\
\hline M_RGWRKB & 0,6318 & 0,0967 & * \\
\hline M_OMVANG & $-0,1459$ & 0,0300 & * \\
\hline M_NONPRF & $-0,4162$ & 0,0395 & * \\
\hline M_VBTMND & 0,0907 & 0,0021 & * \\
\hline $\mathrm{M}^{-} \mathrm{GEOMOB}$ & 0,2195 & 0,0462 & * \\
\hline M_SVANIV & 0,0023 & 0,0178 & \\
\hline M_SMANIV & $-0,0929$ & 0,0208 & * \\
\hline Constant & $-0,2751$ & 0,2131 & \\
\hline
\end{tabular}

${ }^{*}=$ significant op $5 \%$-niveau

$\mathrm{N}=8.835$ (ongewogen aantal) 
Tabel B.5b

Kans op vaste baan (variabele: Y VAST) o.b.v. gegevens HBO-Monitor 1991-1995 (cohorten 1989/1990 t/m 1993/1994)

\begin{tabular}{|c|c|c|c|c|c|}
\hline Variabele & B & S.E. & Sign. & Norm & $\begin{array}{l}\% \text {-verschil } \\
\text { t.o.v. norm }\end{array}$ \\
\hline M JR91 & 0,4750 & 0,0386 & * & 0 & $+11.3 \%$ \\
\hline M_JR92 & 0,3364 & 0,0374 & * & 0 & $+8.0 \%$ \\
\hline M_JR93 & 0,3116 & 0,0343 & * & 0 & $+7.4 \%$ \\
\hline M-JR94 & 0,1276 & 0,0338 & * & 0 & $+3.0 \%$ \\
\hline M_LEEFT & 0,0055 & 0,0041 & & 25 & \\
\hline M_SEXE & 0,0554 & 0,0277 & & 0 & \\
\hline M_VOP.VW & 0,0114 & 0,0309 & & 0 & \\
\hline M-VOP.MB & 0,0679 & 0,0326 & & 0 & \\
\hline M-VOP.HB & $-0,0215$ & 0,0650 & & 0 & \\
\hline M_VOP.AN & $-0,2234$ & 0,0738 & * & 0 & $-5.3 \%$ \\
\hline M_HAO & $-0,3925$ & 0,0579 & * & 0 & $-9,3 \%$ \\
\hline M_HPO & $-0,1107$ & 0,0483 & & 0 & \\
\hline M- HTO & $-0,1361$ & 0,0344 & * & 0 & $-3.2 \%$ \\
\hline M_HGZO & 0,4480 & 0,0458 & * & 0 & $+10.6 \%$ \\
\hline M_HSAO & 0,1041 & 0,0447 & & 0 & \\
\hline M_KUO & $-0,2122$ & 0,0745 & * & 0 & $-5.0 \%$ \\
\hline M_VT_DT & 1,0995 & 0,0551 & * & 0 & $+26.1 \%$ \\
\hline$M \bar{S} S T \bar{J} R$ & $-0,0893$ & 0,0148 & * & 4 & - \\
\hline M_AFSTDR & 0,0588 & 0,0045 & * & 18 & + \\
\hline M_INWKLD & $-0,1853$ & 0,0054 & * & 0 & - \\
\hline M_WRKERV & $-0,1697$ & 0,0258 & * & 1 & $-4.0 \%$ \\
\hline M BSTERV & $-0,0204$ & 0,0265 & & 0 & \\
\hline M_RGWRKN & $-0,0130$ & 0,0489 & & 0 & \\
\hline M_RGWRKO & $-0,1106$ & 0,0317 & * & 0 & $-2.6 \%$ \\
\hline M_RGWRKZ & $-0,0393$ & 0,0298 & & 0 & \\
\hline M_RGWRKB & 0,6715 & 0,0750 & * & 0 & $+15.9 \%$ \\
\hline M־OMVANG & 0,0390 & 0,0249 & & 0 & \\
\hline$M^{\top}$ NONPRF & $-0,3496$ & 0,0315 & * & 0 & $-8.3 \%$ \\
\hline Constant & $-0,2077$ & 0,1390 & & 1 & \\
\hline
\end{tabular}

* $=$ significant op $1 \%$-niveau

$\mathrm{N}=36.670$ (ongewogen aantal) 
Tabel B.6

Kans op full-time baan (variabele Y_FULL35) o.b.v. gegevens HBO-Monitor 1991-1995 (cohorten 1989/1990 t/m 1993/1994)

\begin{tabular}{|c|c|c|c|c|c|}
\hline Variabele & $B$ & S.E. & Sign. & Norm & $\begin{array}{l}\text { \%-verschil } \\
\text { t.o.v. norm }\end{array}$ \\
\hline M_JR91 & 0,2392 & 0,0437 & * & 0 & $+1.6 \%$ \\
\hline M_JR92 & 0,2591 & 0,0442 & * & 0 & $+1.7 \%$ \\
\hline M_JR93 & 0,0530 & 0,0408 & & 0 & \\
\hline M_JR94 & $-0,0372$ & 0,0408 & & 0 & \\
\hline M_LEEFT & $-0,0636$ & 0,0037 & * & 25 & - \\
\hline M_SEXE & $-0,8778$ & 0,0331 & * & 0 & $-5.8 \%$ \\
\hline M_VOP.VW & $-0,0043$ & 0,0380 & & 0 & \\
\hline M_VOP.MB & 0,1148 & 0,0394 & * & 0 & $+0.8 \%$ \\
\hline M_VOP.HB & $-0,2302$ & 0,0611 & * & 0 & $-1.5 \%$ \\
\hline M_VOP.AN & $-0,0568$ & 0,0743 & & 0 & \\
\hline M_HAO & $-0,1089$ & 0,0862 & & 0 & \\
\hline M_HPO & $-0,8524$ & 0,0543 & * & 0 & $-5.6 \%$ \\
\hline M_HTO & 0,5785 & 0,0661 & * & 0 & $+3.8 \%$ \\
\hline M_HGZO & $-1,7337$ & 0,0492 & * & 0 & $-11.4 \%$ \\
\hline M_HSAO & $-1,6163$ & 0,0487 & * & 0 & $-10.6 \%$ \\
\hline M_KUO & $-1,8696$ & 0,0681 & * & 0 & $-12.3 \%$ \\
\hline M_STJR & $-0,0836$ & 0,0165 & * & 4 & - \\
\hline M_AFSTDR & 0,0094 & 0,0052 & & 18 & \\
\hline M_WRKERV & 0,0764 & 0,0307 & & 1 & \\
\hline M_BSTERV & 0,0871 & 0,0315 & * & 0 & $+0.6 \%$ \\
\hline MEVT_DT & 0,1646 & 0,0505 & * & 0 & $+1.1 \%$ \\
\hline M_RGWRKN & $-0,2383$ & 0,0566 & * & 0 & $-1.6 \%$ \\
\hline M_RGWRKO & $-0,1152$ & 0,0364 & * & 0 & $-0.8 \%$ \\
\hline M_RGWRKZ & 0,1090 & 0,0355 & * & 0 & $+0.7 \%$ \\
\hline M_RGWRKB & 1,2225 & 0,0969 & * & 0 & $+8.1 \%$ \\
\hline M_OMVANG & 0,4884 & 0,0304 & * & 0 & $+3.2 \%$ \\
\hline M_NONPRF & $-0,5162$ & 0,0346 & * & 0 & $-3.4 \%$ \\
\hline M_INWKLD & $-0,0699$ & 0,0057 & * & 0 & - \\
\hline Cōnstant & 4,2518 & 0,1524 & * & 1 & \\
\hline
\end{tabular}

* = significant op 1\%-niveau

$\mathrm{N}=38.109$ (ongewogen aantal) 
Tabel B.7a

Kans op baan op minimaal hbo-niveau (variabele: Y_EISHBO) o.b.v. gegevens HBO-Monitor 1995 (cohort 1993/1994)

$\begin{array}{llll}\text { Variabele } & \text { B } & \text { S.E. } & \text { Sign }\end{array}$

\begin{tabular}{|c|c|c|c|}
\hline M_LEEFT & 0,0337 & 0,0047 & * \\
\hline M_HHSMK & 0,2540 & 0,0613 & * \\
\hline M_HHSZK & 0,1633 & 0,0365 & * \\
\hline M_HHAMK & 0,1696 & 0,1415 & \\
\hline M_HHTHU & $-0,0989$ & 0,0454 & * \\
\hline M_SEXE & $-0,2590$ & 0,0353 & * \\
\hline M_ETNIC & 0,4511 & 0,0950 & * \\
\hline M_VOP.VW & 0,1074 & 0,0417 & * \\
\hline M_VOP.MB & $-0,1810$ & 0,0394 & * \\
\hline M_VOP.HB & 0,8096 & 0,0755 & * \\
\hline M_VOP.AN & 0,3598 & 0,0869 & * \\
\hline $\mathrm{M}-\mathrm{HAO}$ & $-0,3020$ & 0,0790 & * \\
\hline $\mathrm{M} \_\mathrm{HPO}$ & 0,6931 & 0,0617 & * \\
\hline M_HTO & 0,5648 & 0,0461 & * \\
\hline M_HGZO & 0,0527 & 0,0595 & \\
\hline M_HSAO & $-0,3284$ & 0,0513 & * \\
\hline M_KUO & $-0,2873$ & 0,0740 & * \\
\hline M_VT_DT & $-0,2731$ & 0,0560 & * \\
\hline M_STJR & 0,0637 & 0,0174 & * \\
\hline M_WRKERV & 0,1699 & 0,0329 & * \\
\hline M_BSTERV & 0,1682 & 0,0353 & * \\
\hline M_AFSTDR & 0,0005 & 0,0051 & \\
\hline M_INWKLD & 0,4928 & 0,0428 & * \\
\hline M_RGWRKN & $-0,1585$ & 0,0689 & * \\
\hline M_RGWRKO & $-0,0302$ & 0,0413 & \\
\hline M_RGWRKZ & 0,1257 & 0,0376 & * \\
\hline M_RGWRKB & 0,2334 & 0,1037 & * \\
\hline M_NONPRF & 0,2358 & 0,0390 & * \\
\hline M_OMVANG & $-0,0111$ & 0,0315 & \\
\hline M_VBTMND & $-0,0099$ & 0,0005 & * \\
\hline M_GEOMOB & 0,2557 & 0,0511 & * \\
\hline M_SVANIV & 0,0617 & 0,0182 & * \\
\hline M_SMANIV & $-0,0059$ & 0,0211 & \\
\hline Constant & $-1,0319$ & 0,2030 & * \\
\hline
\end{tabular}

* = significant op 5\%-niveau

$\mathrm{N}=9.396$ (ongewogen aantal) 
Tabel B.7b

Kans op baan op minimaal hbo-niveau (variabele: $Y$ EISHBO) o.b.v. gegevens HBO-Monitor 1991-1995 (cohorten 1989/1990 t/m 1993/1994)

\begin{tabular}{|c|c|c|c|c|c|}
\hline Variabele & $B$ & S.E. & Sign. & Norm & $\begin{array}{l}\text { \%-verschil } \\
\text { t.o.v. norm }\end{array}$ \\
\hline M_JR91 & 0,0162 & 0,0414 & & 0 & \\
\hline M_JR92 & 0,0625 & 0,0408 & & 0 & \\
\hline M_JR93 & $-0,0167$ & 0,0369 & & 0 & \\
\hline M_JR94 & $-0,0723$ & 0,0365 & & 0 & \\
\hline M_LEEFT & 0,0231 & 0,0039 & * & 25 & + \\
\hline M_SEXE & $-0,1753$ & 0,0294 & * & 0 & $-3.1 \%$ \\
\hline M_VOP.VW & 0,0842 & 0,0343 & & 0 & \\
\hline M_VOP.MB & $-0,1487$ & 0,0344 & * & 0 & $-2.6 \%$ \\
\hline M_VOP.HB & 0,8016 & 0,0703 & * & 0 & $+14.0 \%$ \\
\hline M_VOP.AN & 0,2018 & 0,0753 & * & 0 & $+3.5 \%$ \\
\hline M_HAO & $-0,2912$ & 0,0604 & * & 0 & $-5.1 \%$ \\
\hline M_HPO & 0,7474 & 0,0584 & * & 0 & $+13.1 \%$ \\
\hline M_HTO & 0,4617 & 0,0408 & * & 0 & $+8.1 \%$ \\
\hline M_HGZO & 0,0804 & 0,0465 & & 0 & \\
\hline M_HSAO & $-0,4794$ & 0,0440 & * & 0 & $-8.4 \%$ \\
\hline M_KUO & $-0,2096$ & 0,0720 & * & 0 & $-3.7 \%$ \\
\hline M_VT_DT & $-0,5214$ & 0,0493 & * & 0 & $-9.1 \%$ \\
\hline M_STJR & 0,0597 & 0,0158 & * & 4 & + \\
\hline M_WRKERV & $-0,0251$ & 0,0280 & & 1 & \\
\hline M_BSTERV & 0,2796 & 0,0293 & * & 0 & $+4.9 \%$ \\
\hline M_AFSTDR & $-0,0082$ & 0,0047 & & 18 & \\
\hline M_INWKLD & $-0,0583$ & 0,0050 & * & 0 & - \\
\hline M_RGWRKN & $-0,0959$ & 0,0513 & & 0 & \\
\hline M_RGWRKO & $-0,0367$ & 0,0341 & & 0 & \\
\hline M_RGWRKZ & 0,0269 & 0,0322 & & 0 & \\
\hline M_RGWRKB & 0,3966 & 0,0821 & * & 0 & $+6.9 \%$ \\
\hline M_NONPRF & 0,0383 & 0,0331 & & 0 & \\
\hline M_OMVANG & 0,0021 & 0,0268 & & 0 & \\
\hline Constant & 0,5879 & 0,1426 & * & 1 & \\
\hline
\end{tabular}


Tabel B.8

Kans op baan in de eigen of daaraan verwante richting (variabele: Y_EISTUD) o.b.v. gegevens HBOMonitor 1991-1995 (cohorten 1989/1990 t/m 1993/1994)

\begin{tabular}{|c|c|c|c|c|c|}
\hline Variabele & B & S.E. & Sign. & Norm & $\begin{array}{l}\text { \%-verschil } \\
\text { t.o.v. norm }\end{array}$ \\
\hline M_JR91 & 0,1729 & 0,0442 & * & 0 & $+4.0 \%$ \\
\hline M_JR92 & 0,3586 & 0,0449 & * & 0 & $+8.3 \%$ \\
\hline M_JR93 & 0,3010 & 0,0397 & * & 0 & $+6.9 \%$ \\
\hline M_JR94 & 0,1425 & 0,0386 & * & 0 & $+3.3 \%$ \\
\hline M_LEEFT & $-0,0057$ & 0,0045 & & 25 & \\
\hline M_SEXE & $-0,1452$ & 0,0310 & * & 0 & $-3.4 \%$ \\
\hline M_VOP.VW & $-0,0199$ & 0,0356 & & 0 & \\
\hline M_VOP.MB & 0,1851 & 0,0383 & * & 0 & $+4.3 \%$ \\
\hline M_VOP.HB & 0,3502 & 0,0749 & * & 0 & $+8.1 \%$ \\
\hline M_VOP.AN & $-0,0468$ & 0,0789 & & 0 & \\
\hline M_HAO & 0,0518 & 0,0612 & & 0 & \\
\hline M_HPO & 0,4248 & 0,0584 & * & 0 & $+9.8 \%$ \\
\hline M_HTO & 0,8283 & 0,0411 & * & 0 & $+19.1 \%$ \\
\hline M_HGZO & 1,2283 & 0,0621 & * & 0 & $+28.3 \%$ \\
\hline M_HSAO & 0,2740 & 0,0503 & * & 0 & $+6.3 \%$ \\
\hline M_KUO & 0,3662 & 0,0736 & * & 0 & $+8.5 \%$ \\
\hline M_STJR & $-0,0223$ & 0,0172 & & 4 & \\
\hline M_AFSTDR & $-0,0101$ & 0,0050 & & 18 & \\
\hline M_WRKERV & $-0,1441$ & 0,0301 & * & 1 & $-3.3 \%$ \\
\hline M_BSTERV & $-0,0622$ & 0,0303 & & 0 & \\
\hline M_RGWRKN & $-0,0448$ & 0,0554 & & 0 & \\
\hline M_RGWRKO & 0,0872 & 0,0377 & & 0 & \\
\hline M_RGWRKZ & 0,1718 & 0,0356 & * & 0 & $+4.0 \%$ \\
\hline M_RGWRKB & 0,2647 & 0,0810 & * & 0 & $+6.1 \%$ \\
\hline M_NONPRF & 0,9261 & 0,0382 & * & 0 & $+21.4 \%$ \\
\hline M_OMVANG & 0,0287 & 0,0283 & & 0 & \\
\hline M_INWKLD & $-0,0495$ & 0,0052 & * & 0 & - \\
\hline M_VT_DT & $-0,2526$ & 0,0568 & * & 0 & $-5.8 \%$ \\
\hline Constant & 1,1270 & 0,1549 & * & 1 & \\
\hline
\end{tabular}


Tabel B.9a

Kans op leidinggevende functie (variabele: Y_LEID) o.b.v. gegevens HBO-Monitor 1995 (cohort 1993/1994)

$\begin{array}{llll}\text { Variabele } & \text { B } & \text { S.E. } & \text { Sign. }\end{array}$

\begin{tabular}{|c|c|c|c|}
\hline M_LEEFT & 0,0105 & 0,0043 & * \\
\hline M_HHSMK & 0,1281 & 0,0576 & * \\
\hline M_HHSZK & 0,1959 & 0,0394 & * \\
\hline M_HHAMK & 0,4636 & 0,1249 & * \\
\hline M_HHTHU & $-0,1522$ & 0,0520 & * \\
\hline M_SEXE & $-0,3944$ & 0,0366 & * \\
\hline M_ETNIC & 0,1546 & 0,1048 & \\
\hline M_VOP.VW & $-0,0504$ & 0,0462 & \\
\hline M_VOP.MB & 0,0604 & 0,0435 & \\
\hline M_VOP.HB & $-0,1648$ & 0,0683 & * \\
\hline M_VOP.AN & $-0,1056$ & 0,0824 & \\
\hline $\mathrm{M}$ & $-0,1304$ & 0,0893 & \\
\hline M_HPO & $-1,3806$ & 0,0708 & * \\
\hline M_HTO & 0,0749 & 0,0445 & \\
\hline M_HGZO & $-0,2207$ & 0,0636 & * \\
\hline M_HSAO & $-0,5593$ & 0,0583 & * \\
\hline M_KUO & $-0,8115$ & 0,0918 & * \\
\hline M_STJR & $-0,0621$ & 0,0169 & * \\
\hline M_AFSTDR & $-0,0012$ & 0,0052 & \\
\hline M_WRKERV & 0,4615 & 0,0348 & * \\
\hline M_BSTERV & 0,6031 & 0,0330 & * \\
\hline M_VT_DT & 0,9219 & 0,0540 & * \\
\hline M_RGWRKN & 0,0563 & 0,0767 & \\
\hline M_RGWRKO & 0,0007 & 0,0446 & \\
\hline M_RGWRKZ & $-0,0276$ & 0,0394 & \\
\hline M_RGWRKB & 0,6042 & 0,0953 & * \\
\hline M_NONPRF & $-0,1222$ & 0,0433 & * \\
\hline M_OMVANG & $-0,0977$ & 0,0331 & * \\
\hline M_INWKLD & 0,5128 & 0,0577 & * \\
\hline M_VBTMND & 0,0035 & 0,0005 & * \\
\hline M_GEOMOB & $-0,0759$ & 0,0522 & \\
\hline M_SVANIV & 0,0279 & 0,0192 & \\
\hline M_SMANIV & $-0,0097$ & 0,0222 & \\
\hline Constant & $-2,3204$ & 0,2071 & * \\
\hline
\end{tabular}

* $=$ significant op $5 \%$-niveau

$\mathrm{N}=9.577$ (ongewogen aantal) 
Tabel B.9b

Kans op leidinggevende functie (variabele: Y_LEID) o.b.v. gegevens HBO-Monitor 1991-1995 (cohorten 1989/1990 t/m 1993/1994)

$\begin{array}{llll}\text { Variabele } & \text { B } & \text { S.E. }\end{array}$

\begin{tabular}{|c|c|c|c|}
\hline M_JR91 & 0,3522 & 0,0425 & * \\
\hline M_JR92 & 0,2766 & 0,0421 & * \\
\hline M_JR93 & 0,0925 & 0,0395 & \\
\hline M_JR94 & 0,0251 & 0,0399 & \\
\hline M_LEEFT & 0,0250 & 0,0037 & * \\
\hline M_SEXE & $-0,3245$ & 0,0301 & * \\
\hline M_VOP.VW & $-0,0844$ & 0,0372 & \\
\hline M_VOP.MB & 0,0271 & 0,0372 & \\
\hline M_VOP.HB & $-0,1238$ & 0,0623 & \\
\hline M_VOP.AN & $-0,3178$ & 0,0778 & * \\
\hline M_HAO & $-0,1677$ & 0,0661 & \\
\hline $\mathrm{M}-\mathrm{HPO}$ & $-1,3408$ & 0,0670 & * \\
\hline M_HTO & $-0,1705$ & 0,0386 & * \\
\hline M_HGZO & $-0,4606$ & 0,0499 & * \\
\hline M_HSAO & $-0,6309$ & 0,0507 & * \\
\hline M_KUO & $-0,7938$ & 0,0847 & * \\
\hline M_STJR & $-0,0744$ & 0,0155 & * \\
\hline M_AFSTDR & 0,0217 & 0,0048 & * \\
\hline M_WRKERV & $-0,4962$ & 0,0293 & * \\
\hline M_BSTERV & 0,3819 & 0,0283 & * \\
\hline MEVT_DT & 0,7606 & 0,0479 & * \\
\hline M_RGWRKN & $-0,0632$ & 0,0570 & \\
\hline M_RGWRKO & $-0,0029$ & 0,0367 & \\
\hline M_RGWRKZ & 0,0239 & 0,0342 & \\
\hline M_RGWRKB & 0,7072 & 0,0670 & * \\
\hline M_NONPRF & $-0,2549$ & 0,0364 & * \\
\hline M_OMVANG & $-0,0610$ & 0,0280 & \\
\hline M_INWKLD & $-0,0886$ & 0,0071 & * \\
\hline Cōnstant & $-1,5287$ & 0,1422 & * \\
\hline
\end{tabular}

* = significant op 1\%-niveau

$\mathrm{N}=38.223$ (ongewogen aantal) 
Tabel B.10a

Logaritme op het bruto uurloon (variabele: Y_LNUURL) o.b.v. gegevens HBO-Monitor 1995 (cohort 1993/1994)

$\begin{array}{llll}\text { Variabele } & \text { B } & \text { S.E. } & \text { Sign. }\end{array}$

\begin{tabular}{|c|c|c|c|}
\hline M_LEEFT & 0,010210 & 4,6348E-04 & * \\
\hline M_HHSMK & 0,055639 & 0,006022 & * \\
\hline M_HHSZK & 0,036245 & 0,003660 & * \\
\hline M_HHAMK & $-0,065446$ & 0,013684 & * \\
\hline M_HHTHU & $-0,014591$ & 0,004615 & * \\
\hline M_SEXE & $-0,026349$ & 0,003537 & * \\
\hline M_ETNIC & 0,013594 & 0,009990 & \\
\hline M_VOP.VW & 0,011295 & 0,004122 & * \\
\hline M_VOP.MB & $-0,007338$ & 0,004040 & \\
\hline M_VOP.HB & 0,041455 & 0,006747 & * \\
\hline M_VOP.AN & 0,012757 & 0,008241 & \\
\hline M_HAO & $-0,006430$ & 0,008775 & \\
\hline M_HPO & 0,010523 & 0,005840 & \\
\hline M_HTO & 0,015729 & 0,004387 & * \\
\hline M_HGZO & 0,061706 & 0,006152 & * \\
\hline M_HSAO & 0,018210 & 0,005546 & * \\
\hline M_KUO & $-0,090288$ & 0,008410 & * \\
\hline M_STJR & 0,001367 & 0,001673 & \\
\hline M_AFSTDR & 0,003806 & 5,0573Е-04 & * \\
\hline M_WRKERV & 0,015537 & 0,003298 & * \\
\hline M_BSTERV & 0,026865 & 0,003424 & * \\
\hline M_RGWRKN & $-0,022784$ & 0,007102 & * \\
\hline M_RGWRKO & $-0,040732$ & 0,004155 & * \\
\hline M_RGWRKZ & $-0,027383$ & 0,003714 & * \\
\hline M_RGWRKB & 0,077192 & 0,009583 & * \\
\hline M_OMVANG & 0,034038 & 0,003144 & * \\
\hline M_NONPRF & 0,012250 & 0,003985 & * \\
\hline M_CAD30U & $-0,019140$ & 0,004455 & * \\
\hline M_INWKLD & 0,032913 & 0,004623 & * \\
\hline M_SNTIJD & 0,084328 & 0,010206 & * \\
\hline M_SNVAST & 0,124334 & 0,010143 & * \\
\hline M_EISHBO & 0,113398 & 0,003810 & * \\
\hline M_EISTUD & 0,038574 & 0,003899 & * \\
\hline M_EISERV & 0,046926 & 0,003145 & * \\
\hline M_LEID & 0,032304 & 0,003805 & * \\
\hline M_VT_DT & 0,099427 & 0,005707 & * \\
\hline M_VBTMND & 6,69354E-04 & 5,1198E-05 & * \\
\hline M_GEOMOB & 0,010334 & 0,004825 & * \\
\hline M_SVANIV & 4,20364E-04 & 0,001806 & \\
\hline M_SMANIV & -1,91490E-04 & 0,002074 & \\
\hline (Constant) & 2,274108 & 0,022977 & * \\
\hline
\end{tabular}


Tabel B.10b

Logaritme op het bruto uurloon (variabele: Y_LNUURL) o.b.v. gegevens HBO-Monitor 1991-1995 (cohorten 1989/1990 t/m 1993/1994)

Variabele

B

S.E.

Sign.

M_JR91

M_JR92

M_JR93

M_JR94

M_LEEFT

$M$ SEXE

M_VOP.VW

$M-$ VOP.MB

M_VOP.HB

$M$ VOP.AN

M_HAO

$\mathrm{M}$ HPO

M_HTO

M_HGZO

M_HSA

$M$ KUO

M_STJR

M AFSTDR

M_WRKERV

M BSTERV

M_RGWRKN

M RGWRKO

M_RGWRKZ

M RGWRKB

M_OMVANG

$M$ NONPRF

M_CAD30U

M INWKLD

M_VAST

$M$ EISHBO

M_LEID

$M$ EISTUD

M VT DT

(Constant)

$\begin{array}{rr}-0,034438 & 0,003730 \\ 0,009481 & 0,003645 \\ -0,001627 & 0,003391 \\ 0,006046 & 0,003412 \\ 0,012005 & 3,5742 \mathrm{E}-04 \\ -0,038357 & 0,002690 \\ 0,010747 & 0,003099 \\ 0,004469 & 0,003233 \\ 0,043113 & 0,005771 \\ 0,016845 & 0,006931 \\ -0,018799 & 0,006022 \\ -0,011217 & 0,004910 \\ 0,008606 & 0,003463 \\ 0,048272 & 0,004393 \\ 0,015562 & 0,004342 \\ -0,030237 & 0,007667 \\ 0,002974 & 0,001400 \\ 0,003427 & 4,2661 \mathrm{E}-04 \\ -0,012327 & 0,002573 \\ 0,011844 & 0,002594 \\ -0,019615 & 0,004820 \\ -0,024492 & 0,003144 \\ -0,026430 & 0,002940 \\ 0,063630 & 0,006789 \\ 0,029498 & 0,002460 \\ -0,006658 & 0,003089 \\ -0,060913 & 0,003691 \\ -0,007627 & 5,1656 \mathrm{E}-04 \\ 0,048998 & 0,002558 \\ 0,106237 & 0,002913 \\ 0,041705 & 0,002925 \\ 0,030136 & 0,003169 \\ 0,138394 & 0,004682 \\ 2,476236 & 0,013951\end{array}$

* = significant op 1\%-niveau

$\mathrm{N}=33.171$ (ongewogen aantal)

$R^{2}=0,34$ 
Tabel B.10c

Bruto uurloon (variabele: Y UURLO) o.b.v. gegevens HBO-Monitor 1991-1995 (cohorten 1989/1990 t/m 1993/1994)

\begin{tabular}{|c|c|c|c|c|c|}
\hline Variabele & $B$ & S.E. & Sign. & Norm & $\begin{array}{r}\text { Verschil } \\
\text { t.o.v. norm }\end{array}$ \\
\hline M_JR91 & $-0,714992$ & 0,083763 & * & 0 & $-f 0,70$ \\
\hline M_JR92 & 0,144343 & 0,081852 & & 0 & \\
\hline M_JR93 & $-0,079241$ & 0,076146 & & 0 & \\
\hline M_JR94 & 0,107919 & 0,076621 & & 0 & \\
\hline M_LEEFT & 0,285546 & 0,008026 & * & 25 & $+f 0,30$ (per jaar) \\
\hline M_SEXE & $-0,894394$ & 0,060404 & * & 0 & $-f 0,90$ \\
\hline M_VOP.VW & 0,076368 & 0,069599 & & 0 & \\
\hline M_VOP.MB & $-0,160403$ & 0,072597 & & 0 & \\
\hline M_VOP.HB & 0,851756 & 0,129596 & * & 0 & $+f 0,90$ \\
\hline M_VOP.AN & 0,298281 & 0,155634 & & 0 & \\
\hline $\mathrm{M} \_\mathrm{HAO}$ & $-0,332334$ & 0,135235 & & 0 & \\
\hline M_HPO & $-0,132408$ & 0,110257 & & 0 & \\
\hline M_HTO & 0,067470 & 0,077769 & & 0 & \\
\hline M_HGZO & 1,041481 & 0,098652 & * & 0 & $+f 1,00$ \\
\hline M_HSAO & 0,196996 & 0,097503 & & 0 & \\
\hline M_KUO & $-0,359576$ & 0,172169 & & 0 & \\
\hline M_STJR & 0,012008 & 0,031427 & & 4 & \\
\hline M_AFSTDR & 0,066505 & 0,009580 & * & 18 & $+f 0,10($ per mnd $)$ \\
\hline M_WRKERV & $-0,276640$ & 0,057786 & * & 1 & $-f 0,30$ \\
\hline M_BSTERV & 0,314933 & 0,058261 & * & 0 & $+f 0,30$ \\
\hline M_RGWRKN & $-0,375936$ & 0,108249 & * & 0 & $-f 0,40$ \\
\hline M_RGWRKO & $-0,464063$ & 0,070612 & * & 0 & $-f 0,50$ \\
\hline M_RGWRKZ & $-0,521821$ & 0,066026 & * & 0 & $-f 0,50$ \\
\hline M_RGWRKB & 2,159202 & 0,152450 & * & 0 & $+f 2,20$ \\
\hline M_OMVANG & 0,572860 & 0,055245 & * & 0 & $+f 0,60$ \\
\hline M_NONPRF & $-0,276942$ & 0,069370 & * & 0 & $-f 0,30$ \\
\hline M_CAD30U & $-2,061917$ & 0,082894 & * & 0 & $-f 2,10$ \\
\hline M_INWKLD & $-0,147674$ & 0,011600 & * & 0 & - $f$ 0,10 (per mnd) \\
\hline M_VAS & 0,842666 & 0,057452 & * & 0 & $+f 0,80$ \\
\hline M_EISHBO & 2,009277 & 0,065407 & * & 0 & $+f 2,00$ \\
\hline M_LEID & 0,936450 & 0,065675 & * & 0 & $+f 0,90$ \\
\hline M_EISTUD & 0,437378 & 0,071154 & * & 0 & $+f 0,40$ \\
\hline M_VT_DT & 3,059344 & 0,105134 & * & 0 & $f 3,10$ \\
\hline (Constant) & 10,495009 & 0,313287 & * & 1 & \\
\hline
\end{tabular}

* $=$ significant op 1\%-niveau

$\mathrm{N}=33.171$ (ongewogen aantal)

$R^{2}=0,34$ 
Tabel B.11

Kans op goede/voldoende aansluiting tussen hbo-opleiding en werk (variabele: Y_VANSLW) o.b.v. gegevens HBO-Monitor 1995 (cohort 1993/1994)

$\begin{array}{llll}\text { Variabele } & \text { B } & \text { S.E. } & \text { Sign. }\end{array}$

\begin{tabular}{|c|c|c|c|}
\hline M_LEEFT & $-0,0355$ & 0,0054 & * \\
\hline M_HHSMK & 0,1769 & 0,0693 & * \\
\hline M_HHSZK & 0,0119 & 0,0420 & \\
\hline M_HHAMK & 0,3322 & 0,1649 & * \\
\hline M_HHTHU & $-0,0831$ & 0,0535 & \\
\hline M_SEXE & $-0,0172$ & 0,0411 & \\
\hline M_ETNIC & $-0,2518$ & 0,1194 & * \\
\hline M_VOP.VW & 0,0985 & 0,0475 & * \\
\hline M_VOP.MB & 0,1290 & 0,0467 & * \\
\hline M_VOP.HB & 0,0028 & 0,0766 & \\
\hline M_VOP.AN & $-0,0912$ & 0,0897 & \\
\hline $\mathrm{M}$ - HAO & $-0,3588$ & 0,1025 & * \\
\hline M_HPO & $-0,7098$ & 0,0655 & * \\
\hline M_HTO & $-0,2908$ & 0,0526 & * \\
\hline M_HGZO & $-0,3135$ & 0,0741 & * \\
\hline M_HSAO & $-0,2386$ & 0,0653 & * \\
\hline M_KUO & $-1,4877$ & 0,0849 & * \\
\hline M_STJR & $-0,0798$ & 0,0190 & * \\
\hline M_AFSTDR & $-0,0091$ & 0,0058 & \\
\hline M_WRKERV & 0,1611 & 0,0383 & * \\
\hline M_BSTERV & 0,1335 & 0,0406 & * \\
\hline M_VT_DT & $-0,1072$ & 0,0668 & \\
\hline M_RGWRKN & 0,1137 & 0,0822 & \\
\hline M_RGWRKO & 0,0053 & 0,0480 & \\
\hline M_RGWRKZ & 0,0498 & 0,0433 & \\
\hline M_RGWRKB & 0,2461 & 0,1216 & * \\
\hline M_NONPRF & $-0,0260$ & 0,0454 & \\
\hline M_OMVANG & 0,0420 & 0,0361 & \\
\hline M_INWKLD & 0,1050 & 0,0499 & * \\
\hline M_VBTMND & 0,0010 & 0,0006 & \\
\hline M_GEOMOB & 0,0115 & 0,0563 & \\
\hline M_CAD30U & $-0,0265$ & 0,0606 & \\
\hline M_INKMND & 7,66E-05 & 2,269E-05 & * \\
\hline M_NEVEN & 0,1939 & 0,0581 & * \\
\hline M_SZOPL1 & 1,1504 & 0,0382 & * \\
\hline M_EISHBO & 0,4038 & 0,0422 & * \\
\hline M_EISTUD & 0,6449 & 0,0420 & * \\
\hline M_SVANIV & $-0,0589$ & 0,0209 & * \\
\hline M_SMANIV & 0,0577 & 0,0239 & * \\
\hline Cōnstant & 1,2818 & 0,2407 & * \\
\hline
\end{tabular}

* = significant op 5\%-niveau

$\mathrm{N}=8.259$ (ongewogen aantal) 
Tabel B.12a

Kans op het achteraf kiezen van dezelfde opleiding (variabele: Y SZOPL1) o.b.v. gegevens HBO-Monitor 1995 (cohort 1993/1994), inclusief niet-werkenden

$\begin{array}{llll}\text { Variabele } & \text { B } & \text { S.E. } & \text { Sign }\end{array}$

\begin{tabular}{|c|c|c|c|}
\hline M_LEEFT & 0,0167 & 0,0045 & * \\
\hline M_HHSMK & 0,1034 & 0,0591 & \\
\hline M_HHSZK & 0,1303 & 0,0329 & * \\
\hline M_HHAMK & 0,3416 & 0,1448 & * \\
\hline M_HHTHU & 0,1397 & 0,0388 & * \\
\hline M_SEXE & $-0,0715$ & 0,0318 & * \\
\hline M_ETNIC & 0,2855 & 0,0816 & * \\
\hline M_VOP.VW & $-0,1915$ & 0,0359 & * \\
\hline M_VOP.MB & $-0,0465$ & 0,0370 & \\
\hline M_VOP.HB & $-0,2004$ & 0,0653 & * \\
\hline M_VOP.AN & $-0,0873$ & 0,0771 & \\
\hline M_HAO & 0,1505 & 0,0739 & * \\
\hline M_HPO & 0,2536 & 0,0456 & * \\
\hline M_HTO & 0,0671 & 0,0385 & \\
\hline M_HGZO & 0,5220 & 0,0549 & * \\
\hline M_HSAO & 0,2223 & 0,0485 & * \\
\hline M_KUO & 0,8045 & 0,0670 & * \\
\hline M_STJR & $-0,0909$ & 0,0158 & * \\
\hline M_AFSTDR & $-0,0211$ & 0,0046 & * \\
\hline M_WRKERV & 0,1392 & 0,0295 & * \\
\hline M_BSTERV & 0,0848 & 0,0317 & * \\
\hline M_VT_DT & 0,0029 & 0,0557 & \\
\hline M_INWKKLD & 0,3992 & 0,0364 & * \\
\hline M_SVANIV & $-0,0343$ & 0,0165 & * \\
\hline M_SMANIV & 0,0131 & 0,0189 & \\
\hline M_STUDIE & $-0,1987$ & 0,0545 & * \\
\hline M_WZOEK & $-0,8144$ & 0,0530 & * \\
\hline M_ANSITU & $-0,5494$ & 0,0740 & * \\
\hline Constant & 0,9256 & 0,1783 & * \\
\hline
\end{tabular}

* $=$ significant op $5 \%$-niveau

$\mathrm{N}=11.673$ (inclusief niet-werkenden) 
Tabel B.12b

Kans op het achteraf kiezen van dezelfde opleiding (variabele: Y SZOPL1) o.b.v. gegevens HBO-Monitor 1995 (cohort 1993/1994), exclusief niet-werkenden

\begin{tabular}{llll}
\hline Variabele & B & S.E. & Sign.
\end{tabular}

\begin{tabular}{|c|c|c|c|}
\hline M_LEEFT & 0,0091 & 0,0062 & \\
\hline M_HHSMK & 0,0751 & 0,0756 & \\
\hline M_HHSZK & 0,1268 & 0,0425 & * \\
\hline M_HHAMK & 0,3103 & 0,1834 & \\
\hline M_HHTHU & 0,1208 & 0,0529 & * \\
\hline M_SEXE & $-0,0120$ & 0,0422 & \\
\hline M_ETNIC & 0,4981 & 0,1100 & * \\
\hline M_VOP.VW & $-0,1629$ & 0,0476 & * \\
\hline M_VOP.MB & $-0,0228$ & 0,0479 & \\
\hline M_VOP.HB & $-0,4432$ & 0,0825 & * \\
\hline M_VOP.AN & $-0,1885$ & 0,1000 & \\
\hline $\mathrm{M}$ - HAO & 0,3391 & 0,1064 & * \\
\hline M_HPO & 0,1986 & 0,0687 & * \\
\hline M_HTO & 0,0342 & 0,0495 & \\
\hline M_HGZO & 0,2660 & 0,0769 & * \\
\hline M_HSAO & 0,1685 & 0,0652 & * \\
\hline M_KUO & 1,2610 & 0,1110 & * \\
\hline M_STJR & $-0,0818$ & 0,0201 & * \\
\hline M_AFSTDR & $-0,0330$ & 0,0058 & * \\
\hline M_WRKERV & 0,0348 & 0,0384 & \\
\hline M_BSTERV & 0,0421 & 0,0409 & \\
\hline M_VT_DT & 0,0115 & 0,0722 & \\
\hline M_INW̄'KLD & 0,2709 & 0,0495 & * \\
\hline M_SVANIV & $-0,0211$ & 0,0215 & \\
\hline M_SMANIV & $-0,0019$ & 0,0246 & \\
\hline M_RGWRKN & 0,0339 & 0,0841 & \\
\hline M_RGWRKO & 0,0745 & 0,0504 & \\
\hline M_RGWRKZ & $-0,0807$ & 0,0429 & \\
\hline M_RGWRKB & 0,0942 & 0,1208 & \\
\hline M_NONPRF & 0,2625 & 0,0476 & * \\
\hline M_OMVANG & 0,0342 & 0,0363 & \\
\hline M_GEOMOB & 0,2354 & 0,0585 & * \\
\hline M_CAD30U & $-0,0384$ & 0,0656 & \\
\hline M_INKMND & 0,0001 & 2,460E-05 & * \\
\hline M_NEVEN & $-0,0246$ & 0,0607 & \\
\hline M_EISHBO & 0,4595 & 0,0425 & * \\
\hline M_EISTUD & 0,6268 & 0,0415 & * \\
\hline M_VANSLW & 1,1459 & 0,0383 & * \\
\hline M_VBTMND & 0,0007 & 0,0007 & \\
\hline Cōnstant & $-0,8807$ & 0,2488 & * \\
\hline
\end{tabular}

* = significant op 5\%-niveau

$\mathrm{N}=8.123$ (exclusief niet-werkenden) 